\title{
Thermo-economic and environmental analysis of integrating renewable energy sources in a district heating and cooling network
}

\author{
Muhammad Asim ${ }^{1,2}$, Saad Saleem ${ }^{3}$, Muhammad Imran ${ }^{4}$, Michael K. H. Leung ${ }^{1}$, Syed Asad \\ Hussain $^{5}$, Laura Sisó Miró ${ }^{6} \&$ Ivette Rodríguez ${ }^{7}$ \\ ${ }^{1}$ School of Energy and Environment, City University of Hong Kong, Kowloon, Hong Kong \\ ${ }^{2}$ School of Engineering, University of Management and Technology, C-II, Johar Town, Lahore, Pakistan \\ ${ }^{3}$ Mechanical \& Aerospace Engineering, Oklahoma State University, Stillwater, OK, 74078, USA \\ ${ }^{4}$ School of Engineering and Applied Science, Aston University, Aston Triangle, Birmingham, B4 7ET, UK \\ ${ }^{5}$ Department of Architecture \& Civil Engineering, City University of Hong Kong, Kowloon, Hong Kong \\ ${ }^{6}$ Fundació Institut de Recerca en Energia de Catalunya (IREC), Barcelona, Spain \\ ${ }^{7}$ Universitat Politècnica de Catalunya, ESEIAAT, Colom 11, 08222, Terrassa, Barcelona, Spain
}

\section{Abstract}

This paper presents the technical, environmental and economic evaluation of integrating various combinations of renewable energy sources-based systems in the expansion of a district heating and cooling network of a Technology Park near Barcelona in Spain. At present, a Combined Heat and Power plant running on fossil fuels serves the heating, cooling and electricity demand of the Park. However, this energy demand is expected to increase substantially in the coming years. EnergyPRO software was used to model the energy demand growth till 2030. Validation of the software application was done by making a base model using real plant data from the year 2014. The software was then used to project the energy supply based on three 15-year scenarios, having different combinations of renewable energy technologies, from 2016 until 2030. Primary energy consumption, $\mathrm{CO}_{2}$ emissions and the Net Present Value obtained in each scenario were used to decide the best combinations of renewable energy sources. The results of the study showed that presently, biomass boilers combined with absorption chillers and supported with solar thermal cooling, are the most competitive technologies in comparison to ground source heat pumps for large DHC networks. This is mainly because of the lower primary energy consumption (624,380 MWh/year in 2030 vs. 665,367 MWh/year), higher Net Present Value (NPV) (222 million $€$ vs. 178 million $€$ ), and lower $\mathrm{CO}_{2}$ emissions (107,753 tons/year in 2030 vs. 111,166 tons/year) obtained as a result of the simulations.

Keywords: District heating and cooling, renewable energy integration, energy efficiency, feasibility study, techno economic evaluation 


\section{Nomenclature}

\section{Greek Letters}

$\begin{array}{ll}\eta_{\mathrm{el}} & \text { Electrical efficiency }(\%) \\ \eta_{\mathrm{th}} & \text { Thermal efficiency }(\%)\end{array}$

\section{Subscripts}

$\begin{array}{cc}\text { c } & \text { Cooling } \\ \text { h } & \text { Heating } \\ \text { th } & \text { Thermal } \\ \text { el } & \text { Electric }\end{array}$

\section{Acronyms}

$\begin{array}{llll}\text { BAU } & \text { Business As Usual } & \text { GSHPs } & \text { Ground Source Heat Pumps } \\ \text { CAPEX } & \text { Capital Expenditure } & \text { IT } & \text { Information Technology } \\ \text { CHP } & \text { Combined Heat and Power } & \text { KPIs } & \text { Key Performance Indicators } \\ \mathrm{CO}_{2} & \text { Carbon dioxide } & \text { NZEBs } & \text { Net Zero Energy Buildings } \\ \text { COP } & \text { Coefficient of Performance } & \text { P \& L } & \text { Profit and Loss } \\ \text { DH } & \text { District Heating } & \text { PEF } & \text { Primary Energy Factor } \\ \text { DHC } & \text { District Heating and Cooling } & \text { PTCs } & \text { Parabolic Trough Collectors } \\ \text { EBITDA } & \text { Earnings Before Interests, Taxes } & \text { RES } & \text { Renewable Energy Sources } \\ & \text { Depreciation and Amortization } & & \\ \text { EU } & \text { European Union } & \text { SCBC } & \text { Solar cooling and biomass cooling } \\ \text { GHG } & \text { Green House Gas } & \text { TES } & \text { Thermal Energy Storage }\end{array}$

\section{1. Introduction}

5 The increase in price of fossil fuels, their rapid depletion and environmental impact have 6 accelerated research work in Renewable Energy Sources (RES) and thus RES are playing an

7 important role in future energy systems. Moreover, fossil fuels are a major contribution to 8 greenhouse gas (GHG) emissions, due to which several countries and international bodies are 9 setting immediate goals to combat climate change. The European Union (EU) for instance, has 
set the ambitious target of having at least $27 \%$ share for renewable energy in its total energy mix by 2030 , as per the 2030 climate and energy framework [1].

3 Along with an increased push in using renewables, it must be mentioned that buildings account 4 for $40 \%$ of energy usage and $\mathrm{CO}_{2}$ emissions in the EU [2]. To mitigate the contribution of energy 5 sector to climate change, several policies have been designed and implemented, which supports the development of high-efficiency Combined Heat and Power (CHP) plants in Europe [3]. CHP

7 plants are not only energy efficient, but may also curb $\mathrm{CO}_{2}$ emissions if powered by RES based systems. Thus, to help the EU meet its ambitious targets, integration of RES in District Heating and Cooling (DHC) networks appears to be an excellent solution.

10 Several studies have been carried out for evaluating the technical, economic and environmental 11 feasibility of integrating RES in DHC networks. Dagdougui et al. [4] developed a dynamic 12 model to integrate different RES and a storage device to satisfy the thermal and electric demand 13 of a "Green Building". Wang et al. [5] used a modelling and optimizing technique for 14 developing CHP based District Heating (DH) system, with a solar thermal plant and Thermal 15 Energy Storage (TES) system. Results of the analysis proved that the model is suitable for 16 planning and running CHP-DH systems economically. A simulation was then run with higher 17 proportion of RES and a larger TES, indicating that the TES is utilized more with higher share of 18 RES and a fluctuating load of the CHP-DH system. Østergaard [6], using the EnergyPRO 19 software, developed a 100\% renewable energy scenario for the Danish city of Aalborg and then 20 compared the overall impact on the system of various energy storage systems (DH storage, 21 biogas storage and electricity storage). Nielsen and Moller [7] carried out a study for Denmark 22 where they modelled the integration of solar thermal collectors into Net Zero Energy Buildings 23 (NZEBs) connected to district heating (DH) networks, so that the collectors could satisfy part of 24 the heating demand. The results show that the NZEBs experienced a net decrease in heat supply 25 from the network (CHP units and boilers), and hence decrease in burning of fuels. Streckiene et 26 al. [8] modelled the optimum CHP plant with thermal energy storage that would be most 27 suitable to take advantage of the day ahead German electricity market. The results of the study 28 showed that for a CHP plant supplying 30,000 $\mathrm{MWh}_{\text {th, }}$ thermal energy annually, a $4 \mathrm{MW}_{\mathrm{e}}$ 29 capacity plant with a thermal store would be most technically and economically feasible for 30 participating in the spot market. For district heating systems in Lithuania, Lund et al. [9] did a 
study where they analysed the replacement of old boilers burning fossil fuels with CHP units running on renewable sources such as wood. Results showed that this would considerably

3 decrease fossil fuel consumption by $50-70 \%$ and $\mathrm{CO}_{2}$ emissions by $50 \%$ or $70 \%$ (depending upon the scenario), and also bring down the district heating prices in small towns to the level of those in urban areas. Thermo economic analysis have been performed of district heating and cooling systems connected to ground source heat pumps (GSHPs) in [10], [11], [12] and [13]. Carli et al. [11] showed that in comparison to traditional heat pumps, using GSHPs can reduce primary energy consumption between 50 and $80 \%$. Similar studies, utilizing exergy methods, have been carried out for geothermal district heating systems in [14] and [15]. An interesting thermo economic optimization was performed by Baghernejad et al. [16] of a solar assisted

11 trigeneration (cooling, heating and electricity) system. An optimization model was developed by 12 Buoro et al. [17] for a solar thermal system (with heat storage) integrated with a CHP plant. The 13 study showed that the most economic and environmental friendly scenario is one where the solar 14 field, thermal storage and district heating network operate together. Torchio [18] did an analysis 15 to compare district heating CHP with distributed generation (on-site) CHP. Of the three 16 technologies used for the analysis, fuel cells, micro turbines and internal combustion engines, the 17 results showed that the lowest amount of carbon dioxide emissions was obtained when fuel cells 18 are used as the CHP units in a district heating network. Soltero et al. [19] did a study to replace 19 existing individual heating systems and old coal and nuclear power stations in the Spanish city of 20 Burgos with CHP district heating. Results showed that with this replacement, annually 4 million 21 tons of $\mathrm{CO}_{2}$ emissions could be avoided and profits of 300 million $€$ could be made. Kazagic et 22 al. [20] did a feasibility study for the city of Visoko where they proposed a renewable energy 23 based DH system to replace the current coal fired CHP plants. Although the investment costs 24 were higher for the renewable energy based system, the fuel costs and $\mathrm{CO}_{2}$ emissions were 58\% 25 and $46 \%$ less respectively than that of the coal based system. Rämä et al. [21] did a feasibility 26 study for the city of Helsinki in Finland where they modelled an increased the share of renewable 27 heat sources (solar thermal collectors and water-to-water heat pumps) in the existing DH system. 28 Results showed that heat pumps are a better option when compared to solar collectors, not only in terms of environmental emissions but also cost effectiveness.

30 Despite a large number of publications available on the topic, there is lack of a complete 31 feasibility study i.e., technical, economic and environmental analysis on the establishment of 
1 RES based DHC in a Mediterranean climatic zone in Spain. This may be perhaps because there

2 is generally a lack of regulations for DHC networks in Spain [22]. It is challenging to attract

3 investors for setting up new DHC networks because of the long term amortization, lack of

4 funding from banks and low public investment. Moreover, for cultural and societal reasons,

5 cooling and heating customers prefer individual domestic systems in comparison to collective

6 DHC systems.

7 This article aims to form a basis for promoting DHC networks based on RES. It presents the 8 technical, environmental and economic evaluation of integrating RES for the expansion of an 9 existing DHC system in Parc de 1' Alba, a Technology Park near Barcelona in Spain. The reason

10 for choosing this specific location is the fact that it lies in the region of Catalonia in north east 11 Spain, next to the Mediterranean Sea and bordering France at the Pyrenees mountains. Thus, the 12 region has a variety of different climatic zones, making it a suitable location to establish DHC 13 networks.

14 Currently, a CHP plant, titled ST-4, serves the demand of cooling, heating and electricity of the 15 non-residential consumers but there is a forecast of increased demand over the years. An energy 16 model is created initially and validated, after which the demand growth is modeled. Three 1517 years projection scenarios are created incorporating different combinations of RES. The best 18 combinations of RES are decided based on the $\mathrm{CO}_{2}$ emissions, primary energy consumption and 19 Net Present Value (NPV), which have been considered as the Key Performance Indicators (KPIs).

\section{2. Material and Methods}

21 The detailed layout of the methodology is shown in Figure 1. The very first step, as explained

22 previously, was creation of base model in 2015 to ensure that future analysis of scenarios would 23 be accurate. Real data from the plant (for year 2014) were obtained and provided to EnergyPRO 24 [23] software, which is the primary software tool used for calculations in this study. Based on 25 several inputs including demand profile, weather data, tariffs, efficiencies and capacities of 26 energy conversion units, EnergyPRO gives a comprehensive output on economics, emissions and 27 operational strategy. 


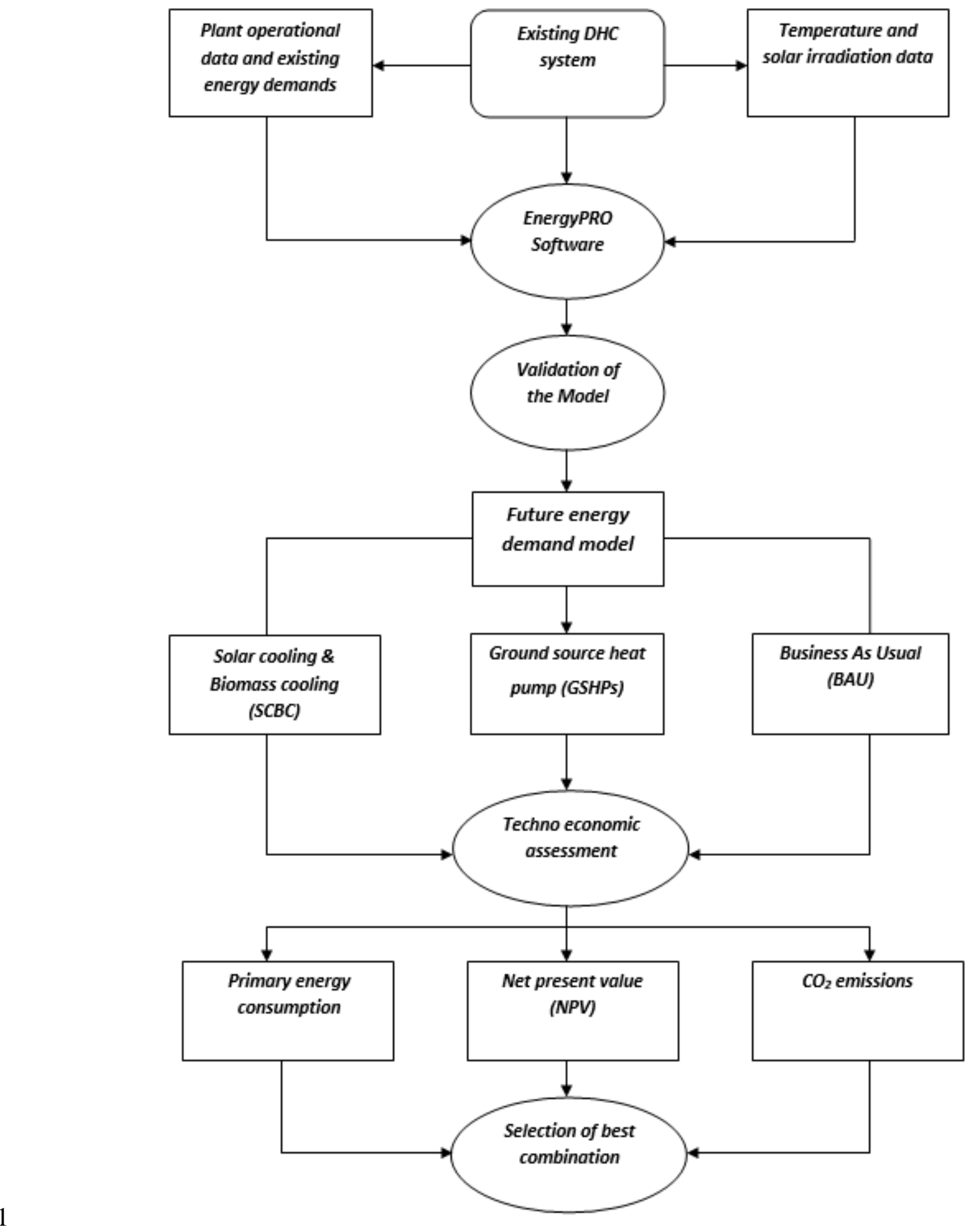

Figure 1: Methodology of the feasibility study

3 The initial inputs to the base model were Time Series of hourly temperature data and solar 4 irradiation of Barcelona. These climate time series were obtained from an online database. To 
generate the electricity market of Spain [24] , the following time series were provided as input:

- Pool Price (TS1) It denotes pool price for the year, continuously varying on hourly basis between $0 € / \mathrm{MWh}_{\mathrm{e}}$ and $114 € / \mathrm{MWh}_{\mathrm{e}}$ for the year 2016

- $\underline{\text { 57€/MWhe (TS3) }}$ Time series with a constant value of $57 € / \mathrm{MWh}_{\mathrm{e}}$ in 2016 . According to Spanish legislation, it corresponds to the payment for system operation

- Spanish Tariff Hours (STH) It denotes fraction of electricity price dependent on different time periods of the day when buying from the grid. Varying on hourly basis between $7.0 € / \mathrm{MWh}_{\mathrm{e}}$ and $27.9 € / \mathrm{MWh}_{\mathrm{e}}$ for the year 2016

Three Time Series Functions were utilized to compute costs and revenue related to electricity export and import. They are:

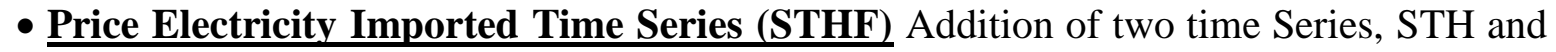
TS1, denoting the amount of money paid by ST-4 if electricity is purchased from the grid. It is defined by equation (1)

$S T H F=S T H+T S 1$

- Price Electricity Exported Time Series (Fu1) Addition of two time series, TS3 and TS1, denoting the amount of money ST-4 earns when electricity is exported to the grid. It is defined by equation (2).

$F u 1=T S 3+T S 1$

- Exported Electricity Tax (Fu2) It denotes the tax paid on 7\% of the electricity exported to the grid. It is defined by equation (3).

$F u 2=F u 1 * 0.07$

Currently, natural gas is burnt in the engines that produce electricity and heat. This heat is sent to the district heating network and is fed to the two absorption chillers to produce cooling for the district cooling network. Excess cooling is stored in the cold-water storage tank. The cooling tower ensures removal of any excess heat from the engines. When electricity prices are low, the engines are turned off. The natural gas boiler and compression chiller serves the heating and 
1 cooling demand respectively; the cold-water storage tank is also discharged in case the 2 compression chiller is not enough. Key details of all energy conversion units and cold storage 3 tank at the ST-4 plant are shown in Table 1. The operating scheme of the plant is shown in 4 Figure 2. It is assumed that the electrical and/or thermal energy conversion efficiencies of the 5 different energy conversion units remains the same even at part load operation.

Table 1: Details of ST-4 plant at Parc de l'Alba (2015)

\begin{tabular}{|c|c|c|c|}
\hline Unit type & Quantity & Specifications (each unit) & Comments \\
\hline Cogeneration Engines & 3 & $\begin{array}{c}3.28 \mathrm{MW}_{\mathrm{th}, \mathrm{h}} ; 3.35 \mathrm{MW}_{\mathrm{e}} ; \eta_{\mathrm{el}} \\
=44.9 \% ; \eta_{\mathrm{th}}=41.1 \%\end{array}$ & $\begin{array}{l}\text { Turned on together whenever } \\
\text { electricity spot markets are high }\end{array}$ \\
\hline $\begin{array}{l}\text { Single Effect Absorption } \\
\text { Chiller }\end{array}$ & 1 & $3 \mathrm{MW}_{\mathrm{th}, \mathrm{c}} ; \mathrm{COP}=0.7$ & $\begin{array}{c}\text { Driven by hot water from the } \\
\text { engines at } 90^{\circ} \mathrm{C}\end{array}$ \\
\hline $\begin{array}{l}\text { Double Effect } \\
\text { Absorption Chiller }\end{array}$ & 1 & $5 \mathrm{MW}_{\mathrm{th}, \mathrm{c}} ; \mathrm{COP}=1.3$ & $\begin{array}{c}\text { Driven by exhaust gases of the } \\
\text { engines at } 398^{\circ} \mathrm{C}\end{array}$ \\
\hline Natural gas boiler & 1 & $5 \mathrm{MW}_{\mathrm{th}, \mathrm{h}} ; \eta_{\mathrm{th}}=60 \%$ & Back-up \\
\hline Compression Chiller & 1 & $5 \mathrm{MW}_{\text {th,c }} ; \mathrm{COP}=5$ & Back-up \\
\hline Cold water storage tank & 1 & $4000 \mathrm{~m}^{3} ; 21 \mathrm{MWh}_{\mathrm{th}, \mathrm{c}}$ & \\
\hline
\end{tabular}




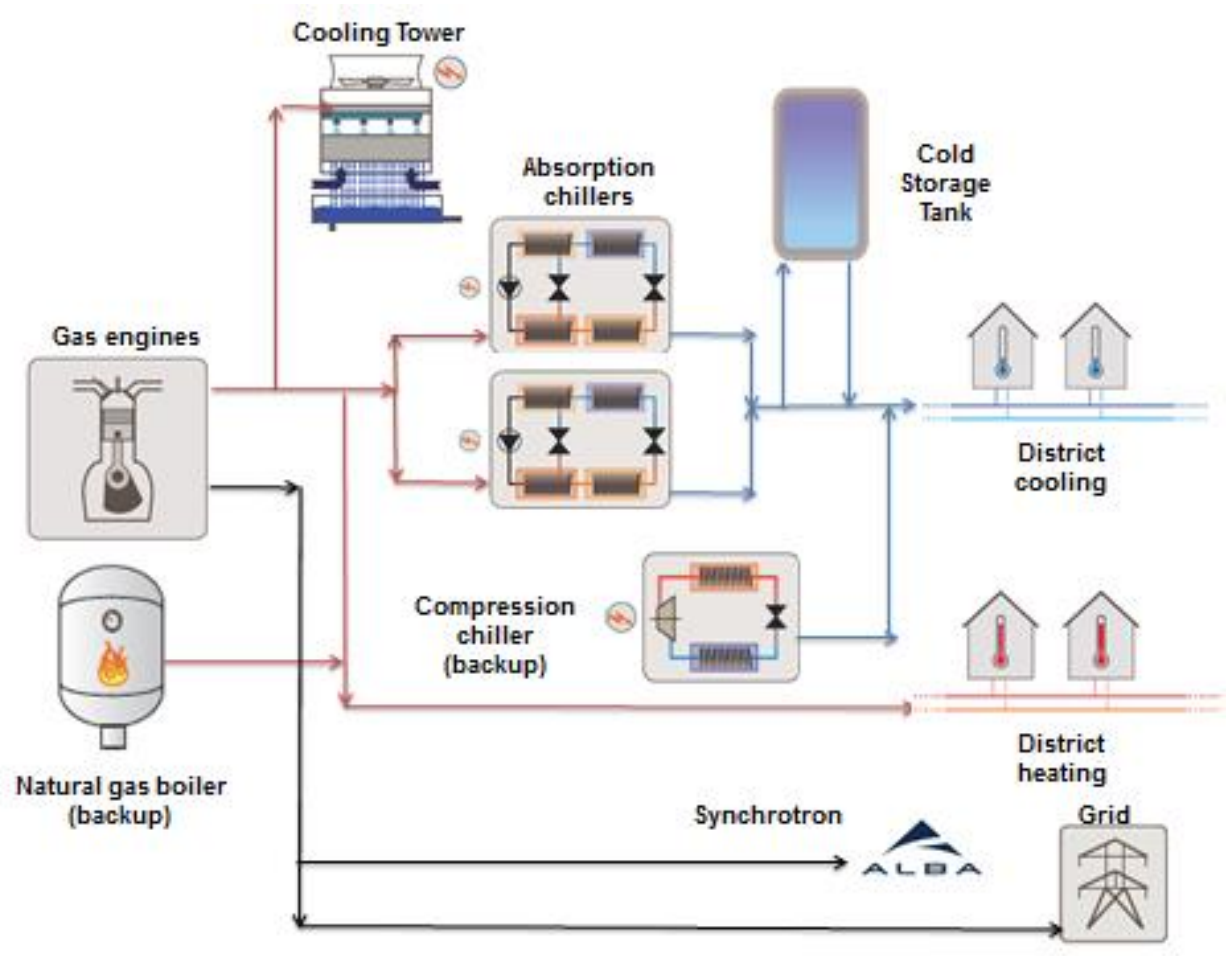

3 The fuel used is natural gas, so it is input to the model with a calorific value of 10.64 $4 \mathrm{kWh} / \mathrm{m}^{3}[25]$. In 2015, the ST-4 plant serves energy demands of the Synchrotron (particle 5 accelerator) facilities and an office building (called "Plot 1" in the scope of this study for reasons 6 of not disclosing the actual name of the client), details of which are shown in Table 2. It needs to 7 be mentioned here that the different demand profiles for the various consumers are not 8 considered for the ones in 2015, but have been taken into account for analysis of future scenarios. 


\begin{tabular}{ccc}
\hline Type of demand & Consumer & Value \\
\hline Cooling demand & Synchrotron & $21,700 \mathrm{MWh}_{\mathrm{th}, \mathrm{c}}$ \\
& Plot 1 & $651 \mathrm{MWh}_{\mathrm{th}, \mathrm{c}}$ \\
Heating demand & Synchrotron & $900 \mathrm{MWh}_{\mathrm{th}, \mathrm{h}}$ \\
& Plot 1 & $530 \mathrm{MWh}_{\mathrm{th}, \mathrm{h}}$ \\
Electricity demand & Synchrotron & $20,400 \mathrm{MWh}_{\mathrm{e}}$ \\
& In-house consumption and losses & $5,320 \mathrm{MWh}_{\mathrm{e}}$ \\
\hline
\end{tabular}

3 The plant generates income not only by selling heating and cooling, but also by selling electricity 4 to the Synchrotron and grid. The Appendix shows details of the revenues, along with the plant 5 expenses, as obtained from the Parc de l'Alba management [25].

6 After providing all the afore mentioned inputs, the simulation was run. The model optimizes 7 plant operation according to the electricity pool prices and electricity production costs. Data was 8 obtained for an entire year from the simulation in hourly basis, and validated against actual 9 results. Table 3 shows the comparison between the actual figures obtained from the plant and the 10 simulation results, for the year 2015 for the months of January, February and July-December. In 11 the months of March-June, the compression chiller had broken down and the resulting change in 12 plant operation was not taken into account by the software. Hence, comparison between 13 simulation and real data for these months is not presented. 
Table 3: Comparison of actual plant operational data of Parc de l' Alba compared against results of the EnergyPRO simulation for selected months of year 2015 (all months of the year excluding March-June)

\begin{tabular}{|c|c|c|c|}
\hline Parameter & Actual data & $\begin{array}{c}\text { Simulation result } \\
\mathrm{s}\end{array}$ & $\begin{array}{r}\text { Percentage } \\
\text { difference }\end{array}$ \\
\hline Cooling demand & $20,500 \mathrm{MWh}_{\mathrm{th}, \mathrm{c}}$ & $22,400 \mathrm{MWh}_{\text {th,c }}$ & $-9 \%$ \\
\hline Heating demand & $1,430 \mathrm{MWh}_{\mathrm{th}, \mathrm{h}}$ & $1,430 \mathrm{MWh}_{\text {th,h }}$ & $0 \%$ \\
\hline Electricity demand & $25,700 \mathrm{MWh}_{\mathrm{e}}$ & $25,700 \mathrm{MWh}_{\mathrm{e}}$ & $0 \%$ \\
\hline Electricity production by gas engines & $35,600 \mathrm{MWh}_{\mathrm{e}}$ & $36,900 \mathrm{MWh}_{\mathrm{e}}$ & $-4 \%$ \\
\hline Exported electricity & $21,900 \mathrm{MWh}_{\mathrm{e}}$ & $25,900 \mathrm{MWh}_{\mathrm{e}}$ & $-18 \%$ \\
\hline Imported electricity & $12,100 \mathrm{MWh}_{\mathrm{e}}$ & $16,400 \mathrm{MWh}_{\mathrm{e}}$ & $-36 \%$ \\
\hline Net electricity export & $9,800 \mathrm{MWh}_{\mathrm{e}}$ & $9,500 \mathrm{MWh}_{\mathrm{e}}$ & $3 \%$ \\
\hline Natural Gas Boiler Fuel consumption & $1,950 \mathrm{MWh}_{\text {th,h }}$ & $1,500 \mathrm{MWh}_{\mathrm{th}, \mathrm{h}}$ & $24 \%$ \\
\hline Natural Gas Boiler Heat production & $1,170 \mathrm{MWh}_{\text {th,h }}$ & $890 \mathrm{MWh}_{\mathrm{th}, \mathrm{h}}$ & $24 \%$ \\
\hline Duration of operation of gas engines & 3,600 hours & 3,700 hours & $-3 \%$ \\
\hline
\end{tabular}

4 Although the simulation results of imported, exported and net exported electricity show a 5 considerable difference from the actual data, it can be deduced that the software is reliable for 6 estimation of future scenarios. This is because the electricity markets of Spain are extremely 7 complex and cannot be very precisely modelled by EnergyPRO.

8 Next, EnergyPRO models were created for the years in which new demands were incorporated, 9 namely 2016, 2017, 2018, 2020, 2025 and 2030. New demands in the corresponding years were 10 inserted into the models, according to the forecast provided by Parc de l' Alba management. In 11 case of the years for which simulations were not performed (2019, 2021-2024 and 2026-2029), it 12 was assumed that the energy performance of the DHC plant(s) remains the same as preceding 
1 simulation year (energy performance of 2019 is identical to 2018, that of 2021 till 2024 is

2 identical to 2020, while that of 2026 till 2029 is identical to 2025). Since EnergyPRO does not

3 have the capability to dimension the distribution network, LOGSTOR calculator [26] was used

4 for calculating the thermal losses for each year in the different scenarios. The information

5 provided to LOGSTOR is shown in the appendix.

6 It was found that the existing plant is enough to satisfy the demand of 2016. However, in 2017,

7 cooling and heating demands increased by $1768 \mathrm{MWh}_{\text {th,c }}$ and $960 \mathrm{MWh}_{\mathrm{th}, \mathrm{h}}$, and thus new energy

8 conversion technologies were implemented henceforth. For the future years, different

9 combinations of RES were used to satisfy the demand, as explained before. The best

10 combinations were decided based on the primary energy consumption, $\mathrm{CO}_{2}$ emissions and NPV.

11 When comparing different fuel types, primary energy consumption is a preferable metric since it

12 considers the energy required to produce one unit of a consumed particular energy on site;

13 including transportation, storage, distribution, delivery and any losses incurred in the process.

$14 \mathrm{CO}_{2}$ emissions were chosen for evaluating environmental feasibility since they contribute the

15 most to climate change. The primary energy consumption and $\mathrm{CO}_{2}$ emissions in each scenario

16 were calculated by simply multiplying the specific emissions factors and Primary Energy Factors

17 (PEFs) respectively of each fuel with the total respective fuel consumption in that scenario. Table

184 shows the PEFs and $\mathrm{CO}_{2}$ emission factors of fuels used in various scenarios taken from

19 [27].These values were assumed to be unchanged for the future years in all scenarios. It should

20 be mentioned here that the low specific emission factors for biogas and biomass might be

21 considered controversial [28]. Even though combustion of biofuels emits carbon that is part of

22 the biogenic carbon cycle, studies and analysis do not always take into account how long does it

23 take for this carbon to return to the biogenic pool from the atmosphere. 
Table 4: Primary Energy Factors and Specific emissions factors for fuels used in Parc de l' Alba

\begin{tabular}{ccc}
\hline Fuel & $\begin{array}{c}\text { Primary Energy } \\
\text { Factor }\end{array}$ & Specific emission factor $(\mathbf{k g ~ C O} /$ unit fuel $)$ \\
\hline Imported Electricity & 2.37 & $0.36 \mathrm{~kg} / \mathrm{kWh}$ \\
Natural gas & 1.20 & $2.68 \mathrm{~kg} / \mathrm{m}^{3}$ \\
Biogas & 0.50 & $0.62 \mathrm{~kg} / \mathrm{m}^{3}$ \\
Biomass & 0.03 & $0.06 \mathrm{~kg} / \mathrm{kg}$ \\
\hline
\end{tabular}

3 For economic feasibility, NPV is chosen as the primary indicator, since it takes into account the 4 time value of money for each scenario, thus showing how profitable was one scenario when 5 compared to another. For this purpose, comprehensive economic calculations are performed by 6 creating Profit and Loss (P \& L) sheets for each scenario, starting from the present (2016), up to 7 the end of the concession period (2047). The procedure followed is outlined in detail by Ross et 8 al. [29]. The NPV, assuming an interest rate of $10 \%$, keeping lifetime of the investment at 31 9 years (with 2016 as year 'zero') is calculated by equation (4). The interest rate of $10 \%$ was 10 chosen based on the author`s experience of conducting economic feasibilities of similar projects.

$N P V=-C_{0}+\sum_{t=1}^{T} \frac{C_{t}}{(1+i)^{t}}$

11 Here, $C_{0}$ is the free cash flow in year zero (in $€$ ), $T$ is the lifetime of investment (in years), $C_{t}$ is 12 the free cash flow in year ' $t$ ' (in $€$ ), ' $i$ ' is the interest rate (in \%) and $t$ represents the time of cash 13 flow (in years). Once the EnergyPRO simulations have provided the revenues and operating 14 expenditures, The Free Cash Flow is obtained by solving several equations in a sequential 15 manner as outlined in [29]. Equation (5) shows how the free cash flow is obtained.

$$
\text { Free cash flow = Operating Cash Flow - Increase in Working capital-CAPEX (5) }
$$

16 The Capital Expenditure (CAPEX) refers to the purchases/investments made in each scenario 
1 whenever new energy conversion units are introduced, the investment varying as per the

2 technologies being used in the scenario. An inflation of $7.48 \%$ was applied to natural gas prices

3 and the variable and fixed prices of heating and cooling; this value is basically the percentage by

4 which gas prices have increased in Spain in the past 13 years according to IEA [30]. Similarly,

5 electricity prices in Spain have increased by $9.72 \%$ per year on average from 1980 till 2012 and

6 this was the inflation applied to variable price of electricity. An inflation of $2 \%$ is assumed for

7 all other costs and revenues [31].

\section{3. Demand modeling}

9 The energy demand growth can be seen graphically in Figure 2 and Figure 3 . Future energy 10 demands were provided by the Parc de l'Alba management.

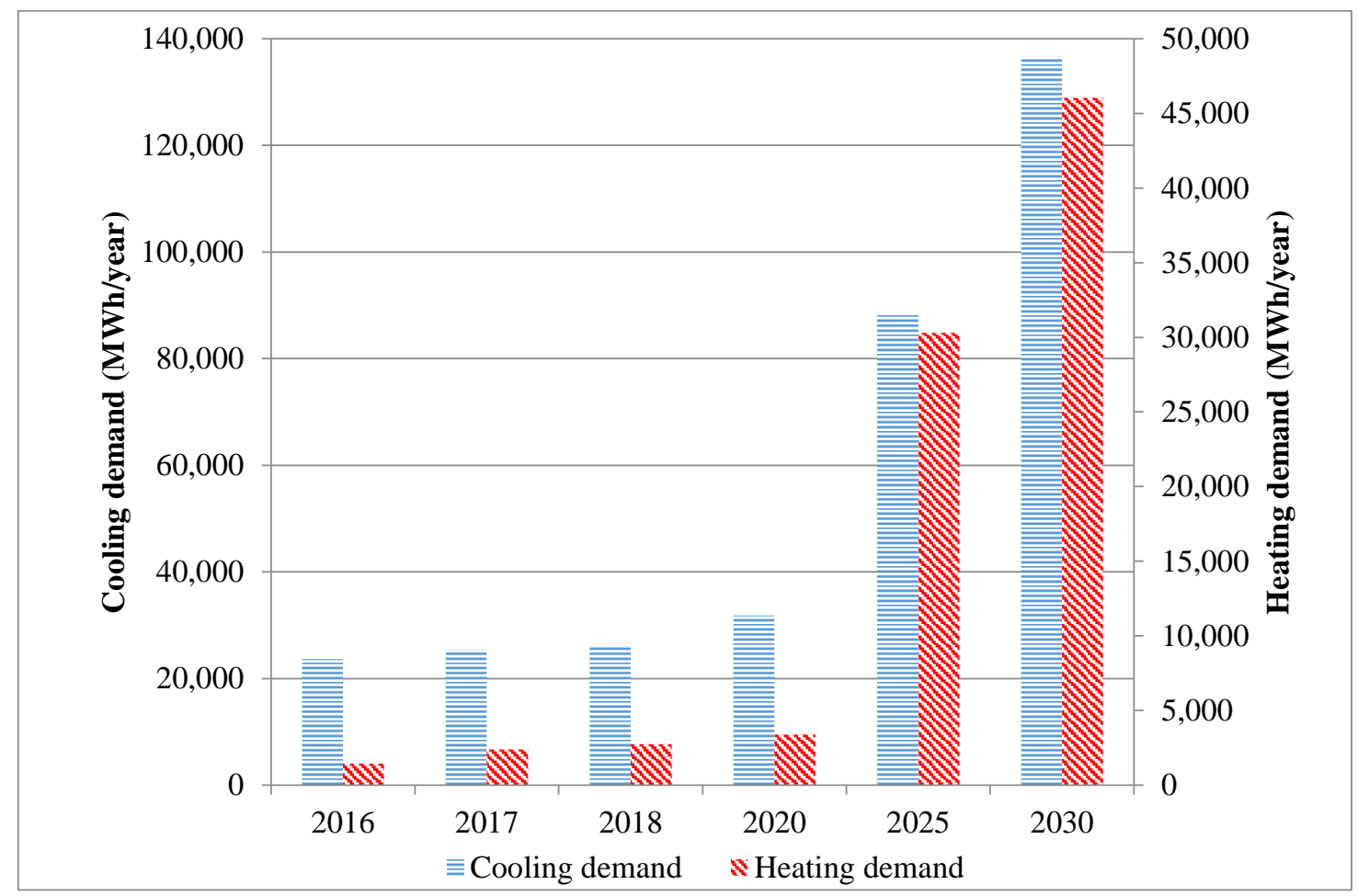

Figure 2 Cooling and heating demand projection of Parc de l'Alba till 2030 


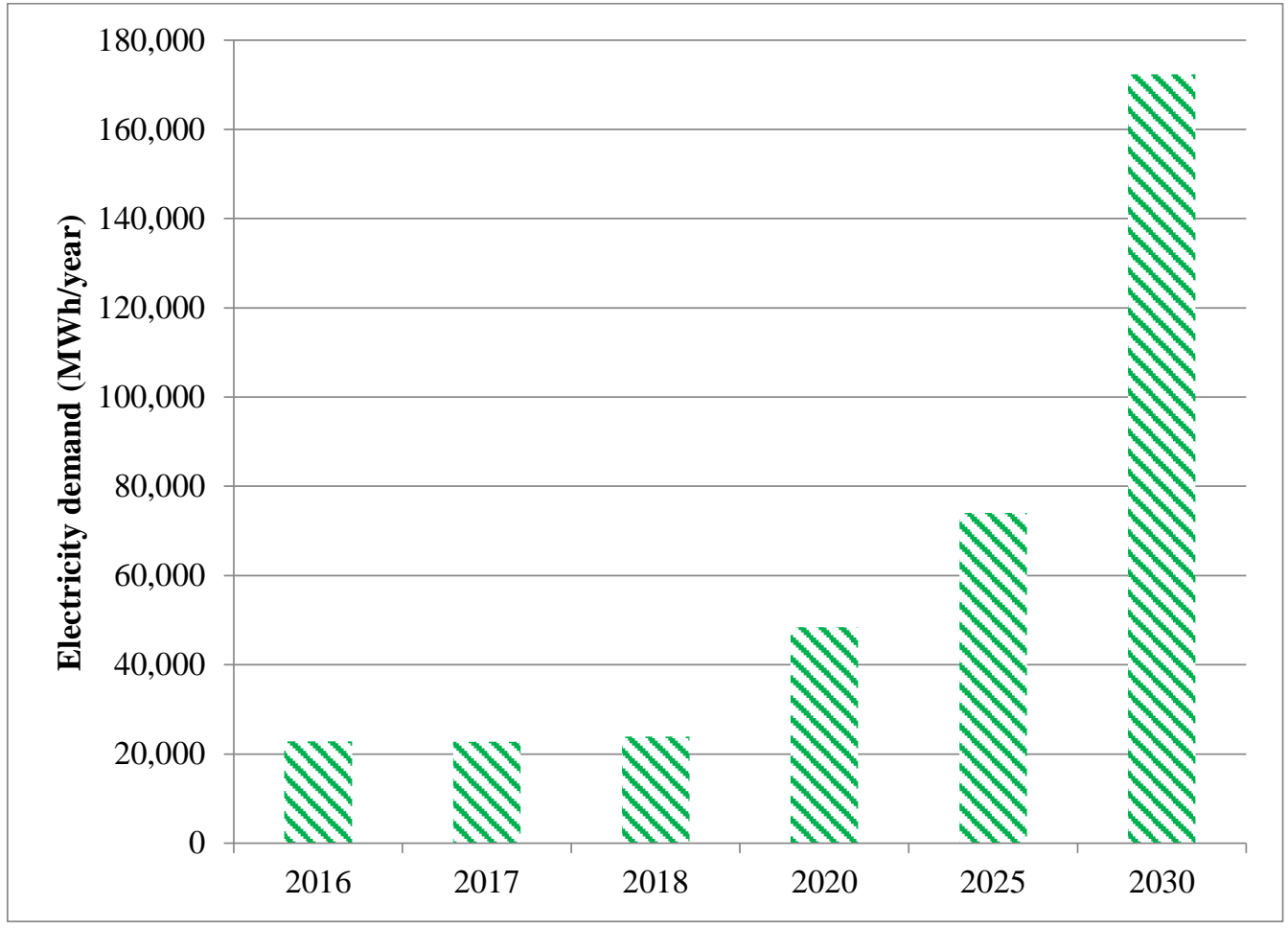

Figure 3 Electricity demand projection of Parc de l' Alba till 2030

3 The transmission and distribution losses for the cooling and heating lines for Parc de l' Alba are 4 shown graphically in Figure 4. It is clear that the heating losses are greater than the cooling 5 losses, indicating that the lines for DH are oversized, in comparison to those for DC. 


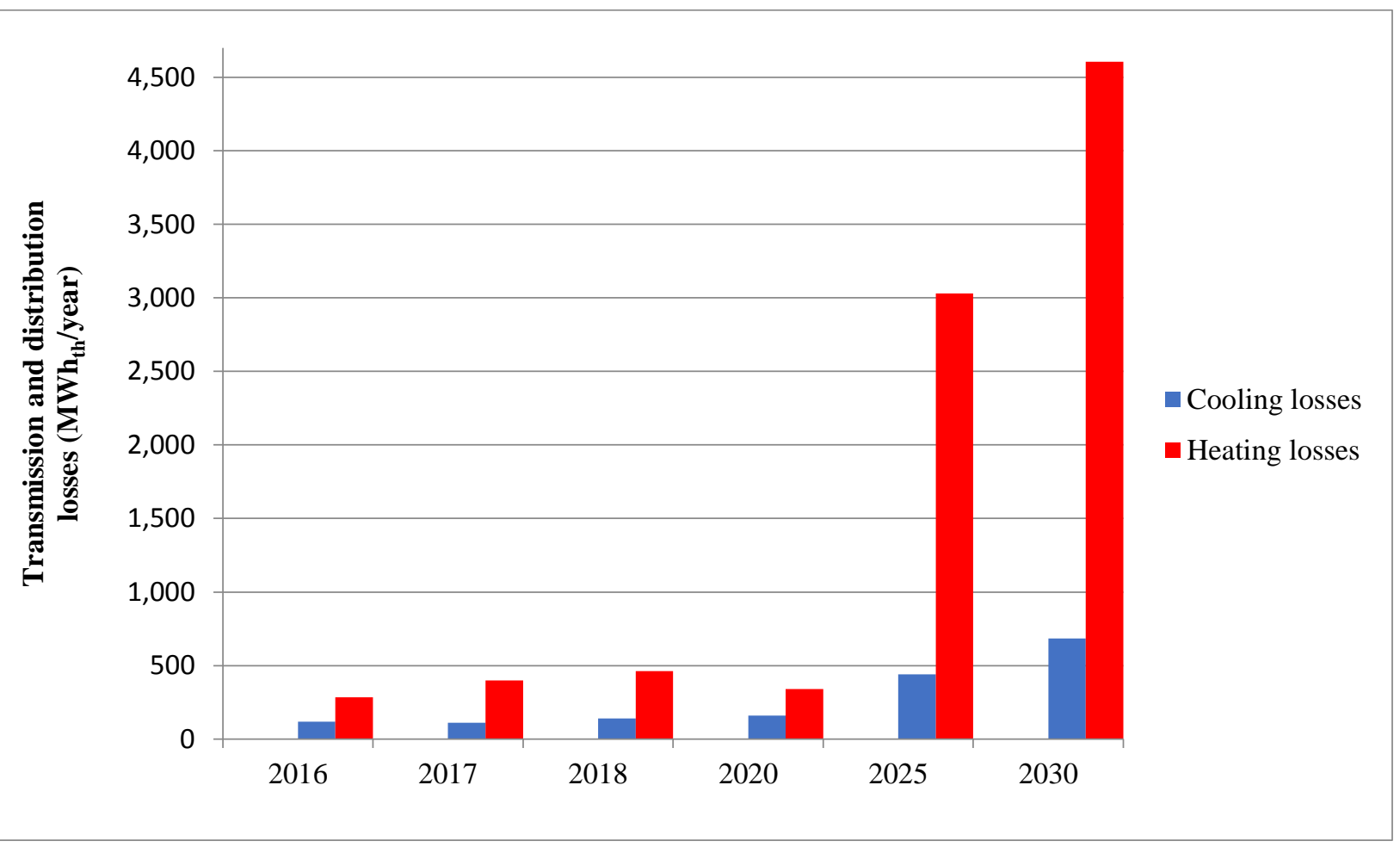

3 The different consumers in Parc de l' Alba are the Synchrotron particle accelerator (cooling and 4 electricity), offices (cooling, heating and electricity) and data centers (cooling and electricity).

5 Details of the energy demand growth are shown in the Appendix in tabular form. All energy 6 demands for the various consumers were inserted as a Time Series for each year. The 7 Synchrotron has a periodic operation throughout the year and hence its cooling and electricity 8 demands were modeled according to the data received from Parc de l' Alba. In the first half of 9 the month of January, the full month of August and second half of December, the Synchrotron 10 itself does not require cooling but its offices do, having a peak demand of 1.3 $\mathrm{MW}_{\text {th,c. }}$. For rest of 11 the year, it operates in cycles: it is in operation for four consecutive weeks (peak demand of 3.3 $12 \mathrm{MW}_{\mathrm{th}, \mathrm{c}}$ ) and out of operation for a week (only its offices require cooling with a peak demand of $131.3 \mathrm{MW}_{\mathrm{th}, \mathrm{c}}$. The electricity demand follows a similar behavior to the cooling demand, the main 14 difference being that the electricity demand is expected to increase by five per cent after 2017; 15 this is input on the software by increasing the peak value of electricity consumption when the 16 Synchrotron is in operation. Figure 5 and Figure 6 show the annual cooling and electricity 17 demand profiles respectively of the Synchrotron 


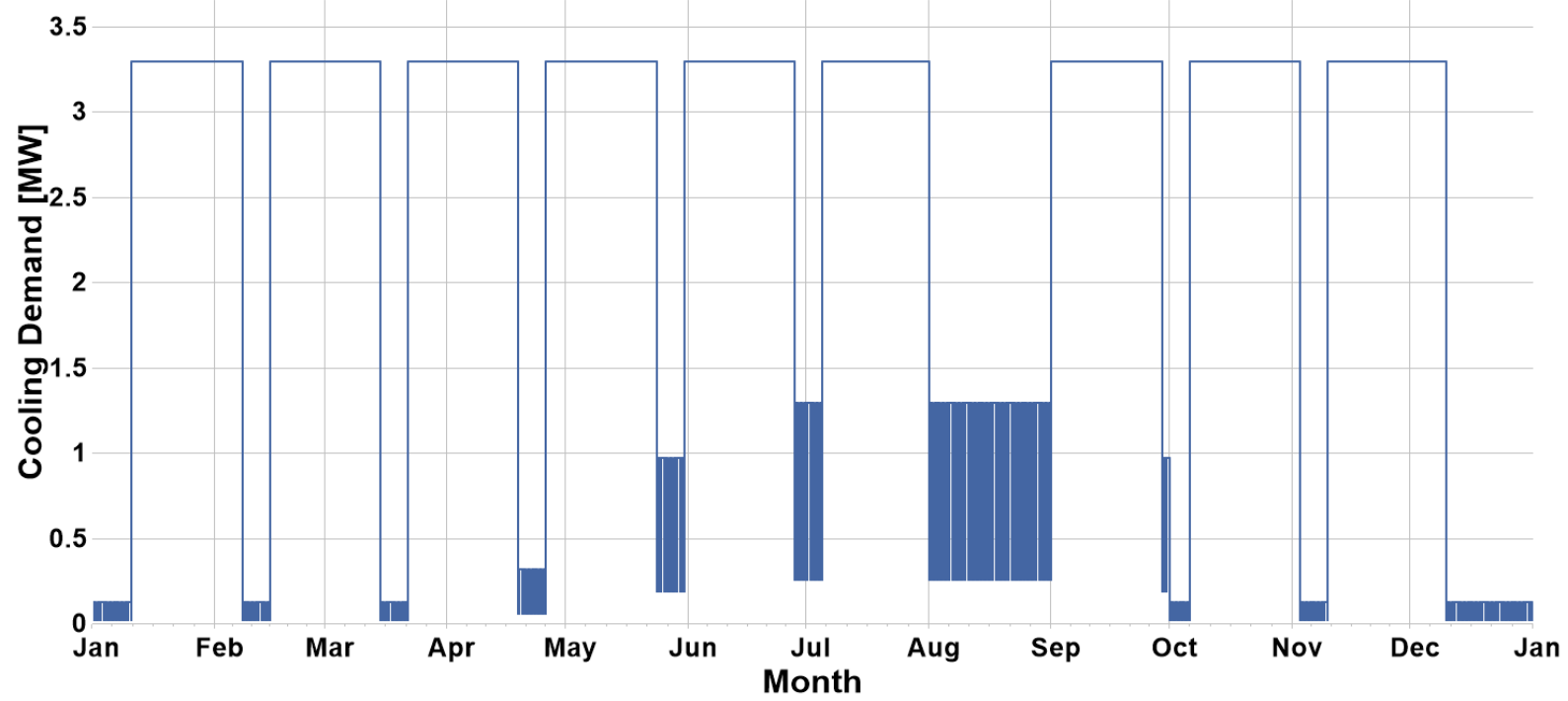

Figure 5: Annual cooling demand profile of Synchrotron facilities

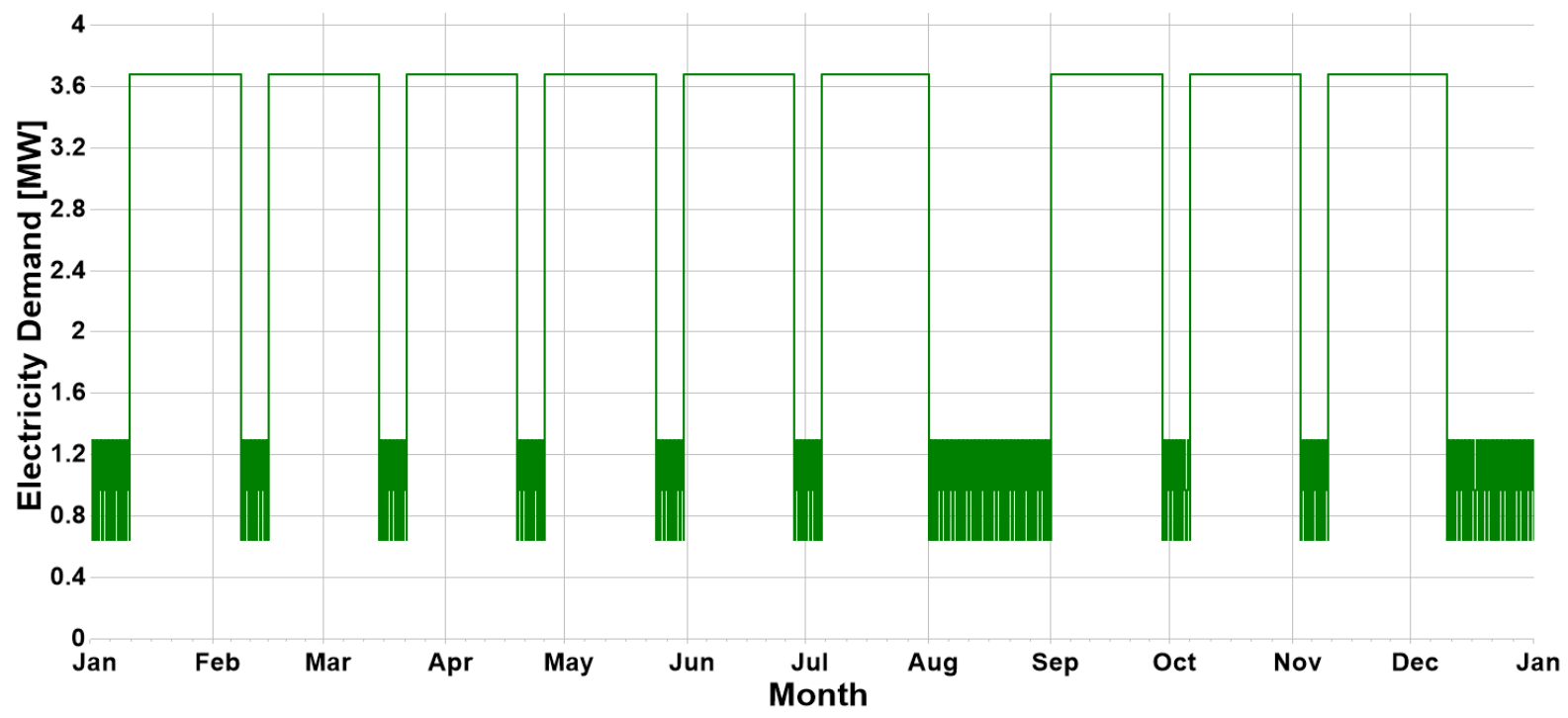

Figure 6: Annual electricity demand profile of Synchrotron facilities

6 A notable difference is there between the demand profiles in Figure 5 and Figure 6; this is

7 because electricity demand is not dependent upon ambient conditions and has the same profile

8 throughout the year.

9 For offices, the cooling and heating demands were modeled according to [32] and [33]. The main 
assumptions for the cooling demand are:

13 Figure 7 and Figure 8 show examples of the annual cooling and heating demand profiles of the 14 offices.
- $45-52 \%$ of the total demand is linearly dependent on the ambient temperature ; it will start when ambient temperature exceeds $18^{\circ} \mathrm{C}$

- The cooling demand has a fixed profile throughout the year , i.e., $100 \%$ cooling from 6 AM to 8 PM from Mondays to Fridays and $20 \%$ at all other times
For heating demand, the main assumptions are:

- $3 \%$ of the demand is allocated to Domestic Hot Water, which is provided throughout the year at all times

- $97 \%$ of the demand is linearly dependent on the ambient temperature ; it will be provided when the ambient temperature is below $18^{\circ} \mathrm{C}$

- The heating demand has a fixed profile throughout the year, i.e., $100 \%$ heating from 6AM to 8PM from Mondays to Fridays and $25 \%$ at all other times

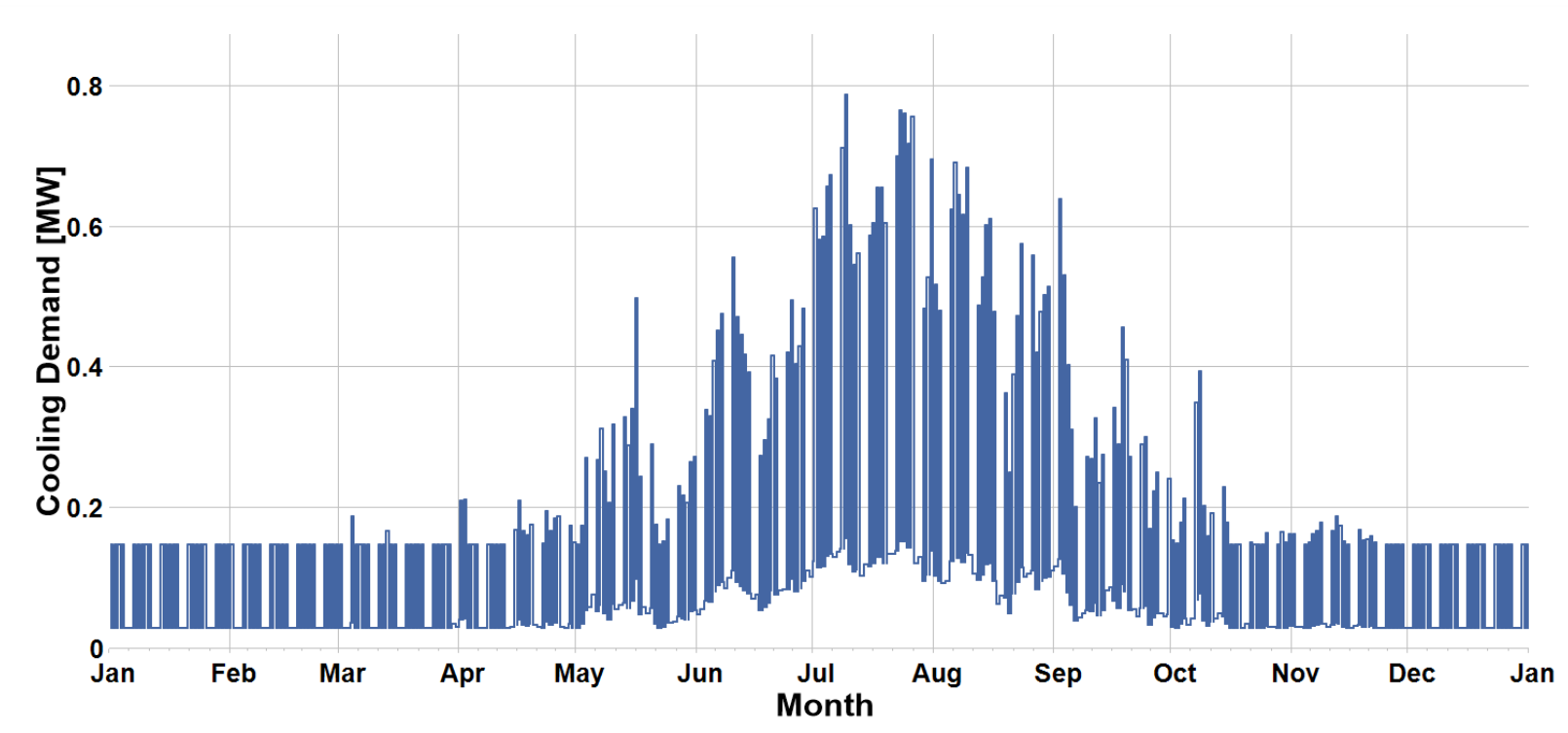

Figure 7: Annual cooling demand profile of office buildings 


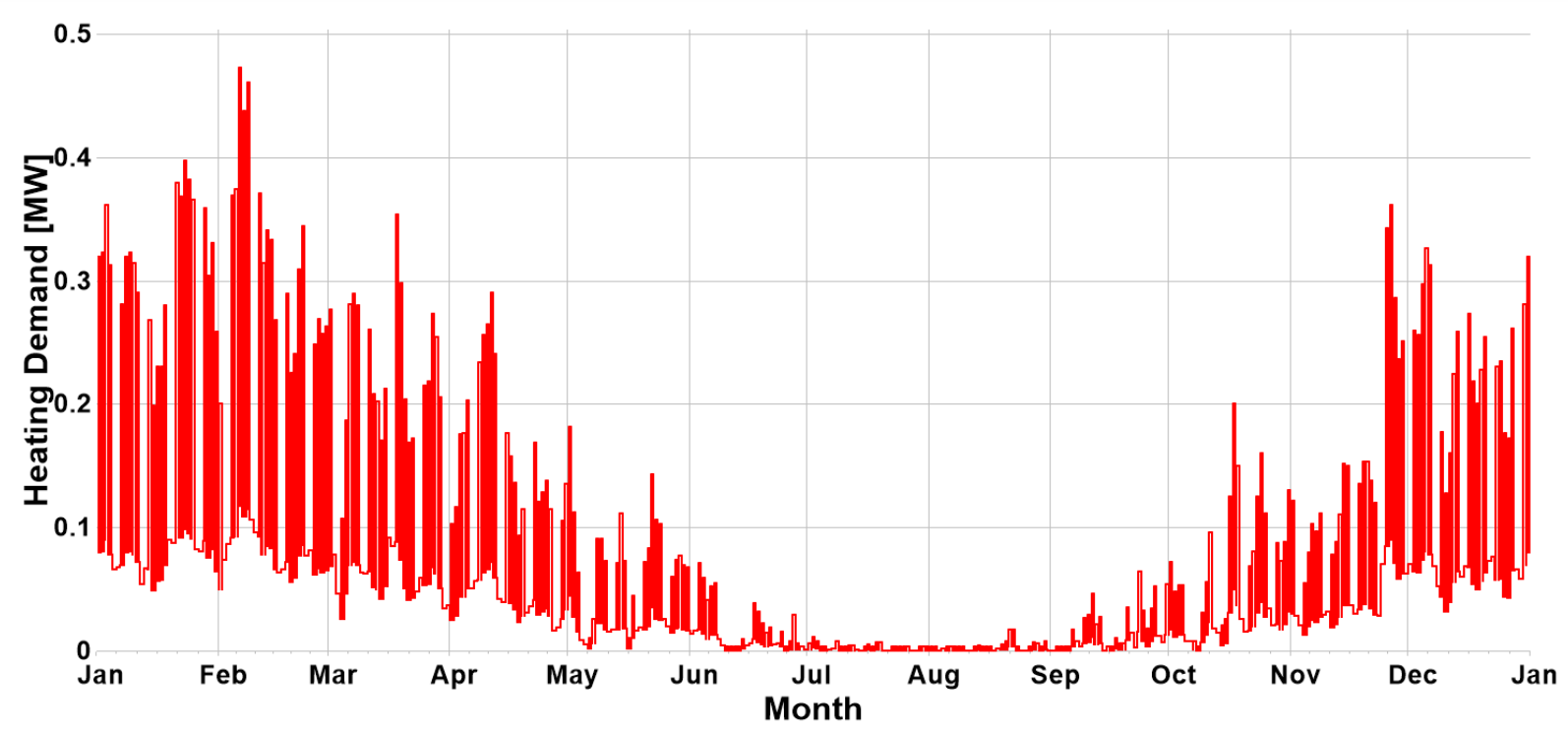

1

4 Finally, cooling and electricity profiles of data centers were characterized on the basis of actual 5 data (operation of IT loads throughout the whole day) simulated in the Renew IT project [34]. To 6 generate the cooling demand profile, TRNSYS software was used. The following inputs were 7 provided to the dynamic simulation models:

8 - Type of workload

9 - Contracted cooling power

11 It was assumed that all data centers handle only data workload (data analytics, data caching and 12 data serving). Figure 9 and Figure 10 show the annual cooling and weekly electricity demand 13 profiles of data centers generated by simulation. The cooling demand profile is more 14 concentrated in the summer season since the data centers are equipped with free cooling, which 15 is active whenever ambient temperature is below $22^{\circ} \mathrm{C}$. The weekly electricity demand remains 16 the same throughout the whole year (as shown in Figure 10). 


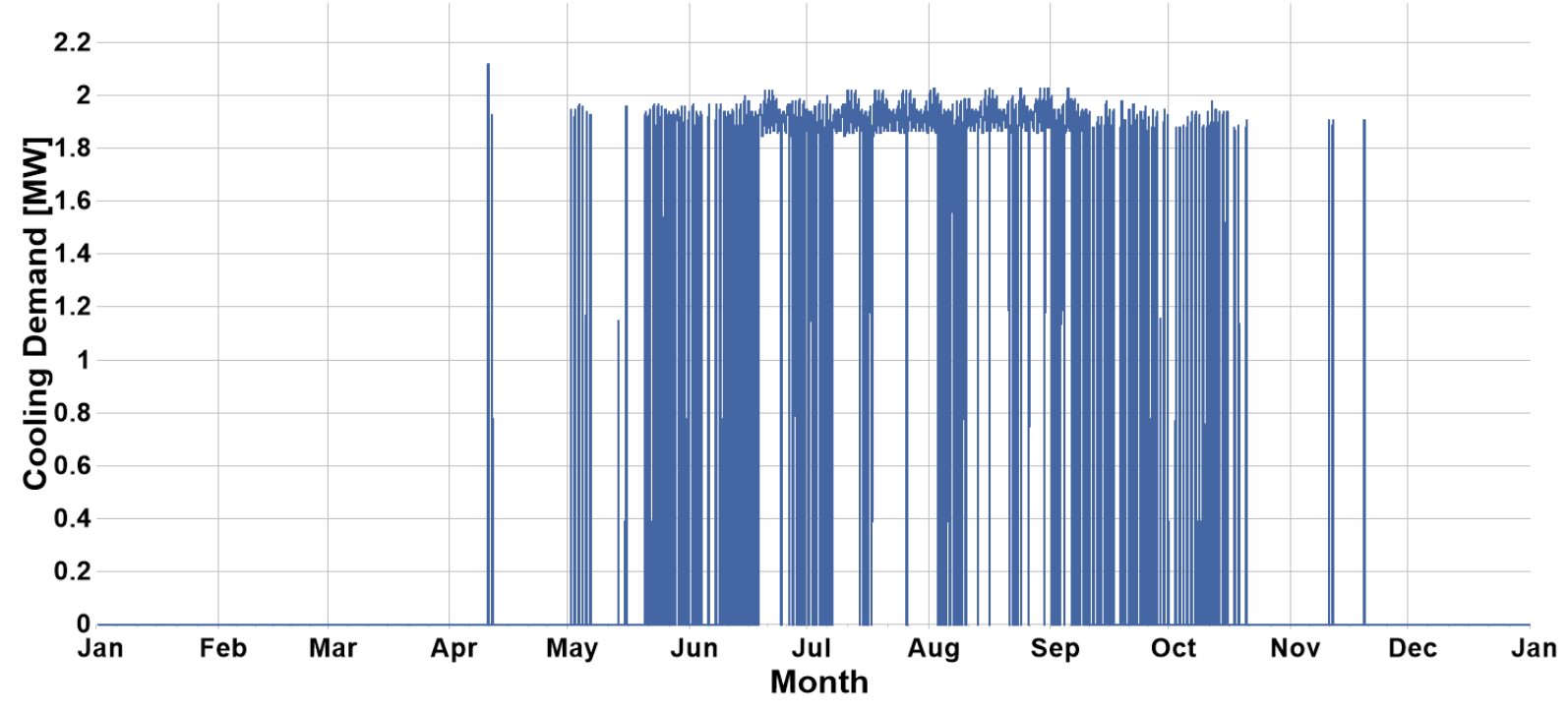

Figure 9: Annual cooling demand profile of data centers

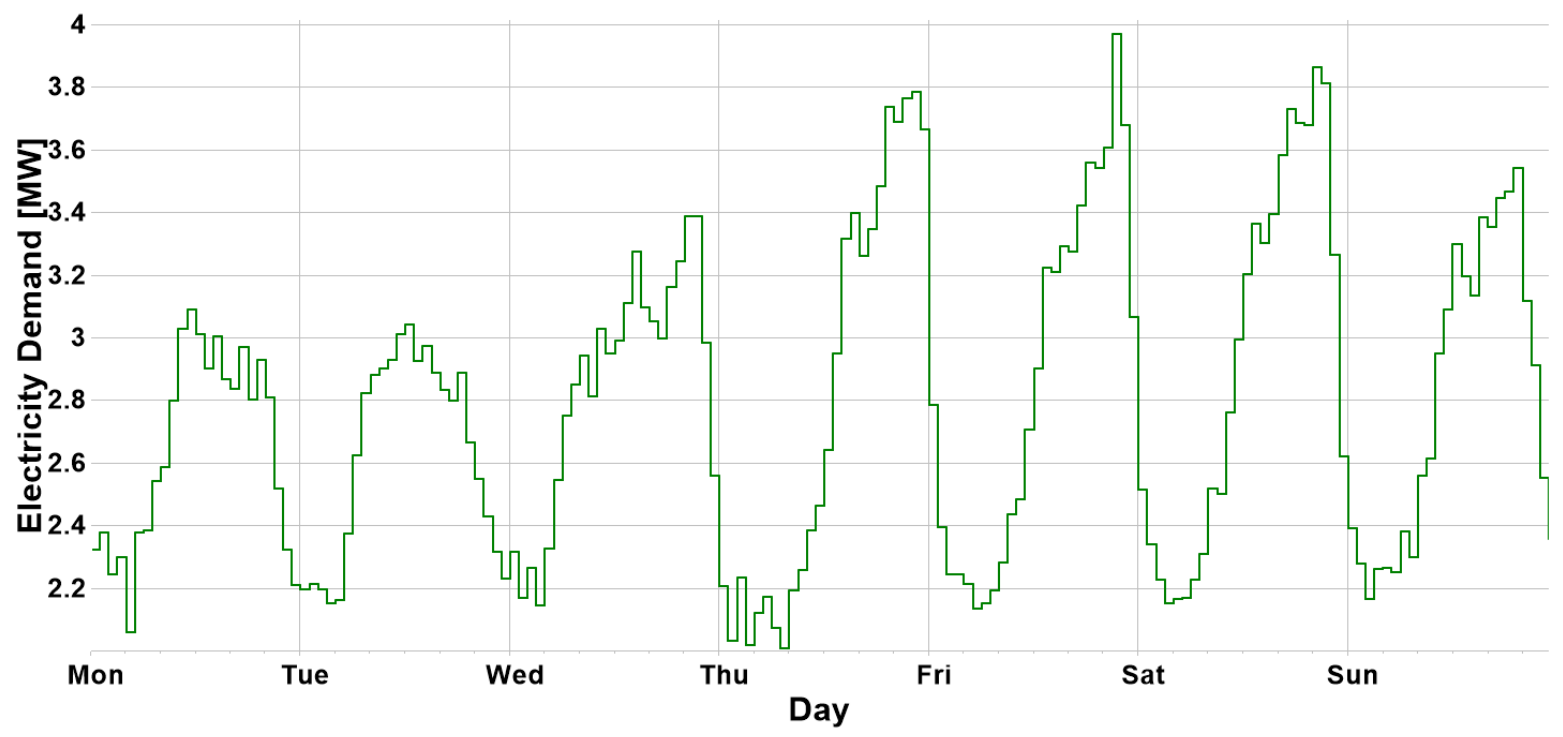

\section{$5 \quad 4 . \quad$ Supply modeling}

6 Three distinct scenarios were considered for supplying the energy demand of Parc de l' Alba. The

7 choice for the combinations of energy conversion units in the different scenarios were mainly 8 dictated by the experience of the authors with previous similar DHC networks in Spain. The 
three scenarios are:

- Scenario 1: Solar cooling and Biomass cooling (SCBC)

- Scenario 2: Ground Source Heat Pumps (GSHPs)

- Scenario 3: Business As Usual (BAU)

5 Common to all scenarios is the incorporation of a biogas boiler in the ST-4 plant in 2017, which

6 is taken out of service in 2020 (due to unavailability of fuel i.e., landfill gas, from 2020 onwards).

7 The biogas boiler has a capacity of $1.5 \mathrm{MW}_{\text {th,h }}$, with a thermal efficiency of $90 \%$.

8 From 2020 to 2030 (both inclusive), the demand is large enough to implement different energy 9 conversion technologies in the new ST-5 plant. The peak power demands dictated the sizing of 10 energy conversion units in these years. In all simulations, the operation strategy provided to the 11 software was such that energy conversion units that produced energy most economically would 12 run first and so on. For sizing the cold-water storage tanks, data was obtained from the Forum 13 and 22@ DHC networks in Barcelona in Spain [25]. A cooling demand to volume ratio of 5

$14 \mathrm{MWh}_{\mathrm{th}, \mathrm{c}} / \mathrm{year} / \mathrm{m}^{3}$ was defined to relate the cooling demand with cold storage size and was hence 15 used to size the cold-water storage tanks in 2020, 2025 and 2030. For hot storage, it was assumed 16 that $20 \%$ of the heating demand would need to be stored, considering a storage time of 12 hours. 17 Table 5 shows details of hot and cold storages added in 2020, 2025 and 2030 in the simulations.

Table 5: Volume and capacities of cold and hot storage tanks at ST-5 plant (2020-2030)

2020 2025 2030

Cold water storage tank

Hot water storage tank

$$
6400 \mathrm{~m}^{3} ; 29.8 \mathrm{MWh}_{\text {th,c }} \quad 11300 \mathrm{~m}^{3} ; 52.4 \mathrm{MWh}_{\text {th,c }} \quad 9700 \mathrm{~m}^{3} ; 45.0 \mathrm{MWh}_{\text {th,c }}
$$

$$
200 \mathrm{~m}^{3} ; 5.8 \mathrm{MWh}_{\mathrm{th}, \mathrm{h}} \quad 1620 \mathrm{~m}^{3} ; 47.0 \mathrm{MWh}_{\mathrm{th}, \mathrm{h}} \quad 1000 \mathrm{~m}^{3} ; 29.0 \mathrm{MWh}_{\mathrm{th}, \mathrm{h}}
$$

20 Another important point to be mentioned is that the existing ST-4 plant still has space for 21 installation of two new cogeneration engines and an absorption chiller. Thus, in all scenarios, it 22 was decided to install two new engines and an absorption chiller in 2025, having specifications 
1 shown in Table 6. The back-up natural gas boiler at the ST-4 is only allowed to run in the winter

2 months for Scenarios 1 and 2, while it can run throughout the whole year for Scenario 3.

Table 6: Technical specifications of equipment installed at ST-4 plant in 2025 (all scenarios)

\begin{tabular}{ccc} 
Energy Conversion unit & Specifications & Quantity \\
\hline Cogeneration engines & $3350 \mathrm{~kW}_{\mathrm{e}} ; 3280 \mathrm{~kW}$ th, $; \eta_{\mathrm{el}}=44.9 \% ; \eta_{\text {th }}=41.1 \%$ & 2 \\
Double effect absorption \\
chiller
\end{tabular}

4

5 4.1. Scenario 1: Solar Cooling and Biomass Cooling (SCBC)

6 For this scenario, it is assumed that the rooftop of the ST-5 plant was used to install parabolic

7 trough collectors (PTCs). The hot water from these PTCs would be supplied to a double effect

8 absorption chiller to produce cooling. For the remainder (major) cooling demand and heating

9 demand, biomass boilers are installed and connected to double effect absorption chillers. Details

10 of all energy conversion units installed in SCBC scenario are shown in Table 7.

11

12

13

14

15

16

17

18 
Table 7: Technical specifications of equipment installed in SCBC scenario (2020-2030)

\begin{tabular}{|c|c|c|c|c|c|}
\hline \multirow[t]{2}{*}{$\begin{array}{c}\text { Energy } \\
\text { Conversion unit }\end{array}$} & \multirow[t]{2}{*}{ Specifications } & \multicolumn{3}{|c|}{$\begin{array}{c}\text { Quantity installed each } \\
\text { year }\end{array}$} & \multirow{2}{*}{$\begin{array}{c}\text { Total installed } \\
\text { capacity by } \\
2030\end{array}$} \\
\hline & & 2020 & 2025 & 2030 & \\
\hline $\begin{array}{l}\text { Parabolic trough } \\
\text { collectors }\end{array}$ & $\begin{array}{c}1088 \mathrm{~m}^{2} ; 298 \mathrm{~kW}_{\text {th }}(417 \\
\left.\mathrm{kW}_{\text {th,c }}\right)\end{array}$ & 1 & - & - & $\begin{array}{c}298 \mathrm{~kW}_{\text {th }}(417 \\
\left.\mathrm{kW}_{\text {th,c }}\right)\end{array}$ \\
\hline $\begin{array}{l}\text { Absorption chiller } \\
\text { (connected to solar } \\
\text { collectors) }\end{array}$ & $450 \mathrm{~kW}_{\text {th,c }} ; \mathrm{COP}=1.4$ & 1 & - & - & $450 \mathrm{~kW}_{\mathrm{th}, \mathrm{c}}$ \\
\hline Biomass boiler & $\begin{array}{l}2,500 \mathrm{~kW}_{\mathrm{th}, \mathrm{h}} ; \eta_{\mathrm{th}}=90 \% \\
5,000 \mathrm{~kW}_{\mathrm{th}, \mathrm{h}} ; \eta_{\mathrm{th}}=90 \%\end{array}$ & $\begin{array}{l}1 \\
-\end{array}$ & $\begin{array}{l}1 \\
5\end{array}$ & - & $55,000 \mathrm{~kW}_{\mathrm{th}, \mathrm{h}}$ \\
\hline \multicolumn{6}{|l|}{ Absorption } \\
\hline $\begin{array}{l}\text { (connected to } \\
\text { biomass boiler) }\end{array}$ & $5,000 \mathrm{~kW}_{\mathrm{th}, \mathrm{c}} ; \mathrm{COP}=1.4$ & - & 6 & 3 & $51,600 \mathrm{~kW}_{\text {th, }}$ \\
\hline
\end{tabular}

4.2. Scenario 2: Ground Source Heat Pumps (GSHPs)

4 In the GSHPs scenario, the cooling and heating demands are supplied by ground source heat 5 pumps (GSHPs) that produce cooling and heating at the same time. The GSHPs produce 3.2 6 units of cooling and 4.2 units of heating, for every unit of electricity input to the compressor 7 (these specifications are assumed to be the same as those of the units used in hospital de Mollet 8 project in Spain [35]). As a consequence of higher heat output in comparison with cooling output 9 for the same input, the GSHPs in this scenario are "oversized" in terms of heating capacity (since 10 cooling demand is always higher than heating demand in Parc de l' Alba and it is assumed that 11 there is no drift in soil temperature occurring due to imbalance between the two types of thermal 12 loads). Since GSHPs require very large areas of land on-site for digging boreholes, no new 13 GSHPs are installed in 2030 and the new cooling and heating demands for that year are supplied 14 by biomass boilers connected to double effect absorption chillers. Details of all energy 15 conversion units installed in GSHPs scenario are shown in Table 8. 
Table 8: Technical specifications of equipment installed in GSHPs scenario (2020-2030)

\begin{tabular}{|c|c|c|c|c|c|}
\hline \multirow[t]{2}{*}{$\begin{array}{c}\text { Energy } \\
\text { Conversion unit }\end{array}$} & \multirow[t]{2}{*}{ Specifications } & \multicolumn{3}{|c|}{$\begin{array}{c}\text { Quantity installed each } \\
\text { year }\end{array}$} & \multirow{2}{*}{$\begin{array}{c}\text { Total installed } \\
\text { capacity by } \\
2030\end{array}$} \\
\hline & & 2020 & 2025 & 2030 & \\
\hline & $1800 \mathrm{~m}^{2} ; 275 \mathrm{~kW}_{\mathrm{e}} ; \eta_{\mathrm{el}}=1$ & & & & \\
\hline Solar PV system & $\begin{array}{l}\text { 5.4\%, Type: Monocrysta } \\
\text { lline }\end{array}$ & 1 & - & - & $275 \mathrm{~kW}_{\mathrm{e}}$ \\
\hline \multirow{5}{*}{$\begin{array}{c}\text { Ground Source He } \\
\text { at } \\
\text { Pumps }\end{array}$} & Input: $1214 \mathrm{~kW}_{\mathrm{e}}$; & & & & \multirow{5}{*}{$\begin{array}{l}34,00 \mathrm{~kW}_{\mathrm{th}, \mathrm{c}} \\
5,113 \mathrm{~kW}_{\mathrm{th}, \mathrm{h}}\end{array}$} \\
\hline & Output: $3900 \mathrm{~kW}_{\mathrm{th}, \mathrm{c}}, 5113$ & 1 & - & - & \\
\hline & $\mathrm{kW}_{\mathrm{th}, \mathrm{h}}$ & & & & \\
\hline & Input: 9,368 kW & & & & \\
\hline & Output: $30,100 \mathrm{~kW}_{\mathrm{th}, \mathrm{c}}, 394$ & - & 1 & - & \\
\hline \multirow{3}{*}{$\begin{array}{c}\text { Biomass boilers } \\
\text { Absorption Chiller } \\
\text { s }\end{array}$} & $61 \mathrm{~kW}_{\mathrm{th}, \mathrm{h}}$ & & & & \\
\hline & $5000 \mathrm{~kW}_{\mathrm{th}, \mathrm{h}} ; \eta_{\mathrm{th}}=90 \%$ & - & - & 5 & $25,000 \mathrm{~kW}_{\mathrm{th}, \mathrm{h}}$ \\
\hline & $5000 \mathrm{~kW}_{\mathrm{th}, \mathrm{c}} ; \mathrm{COP}=1.4$ & - & - & 5 & $25,000 \mathrm{~kW}_{\text {th, h }}$ \\
\hline
\end{tabular}

$3 \quad$ 4.3. $\quad$ Scenario 3: Business as Usual (BAU)

4 In the BAU scenario, cogeneration engines are installed to sell electricity directly to the data 5 centers from 2020 onwards (as opposed to buying it from the grid and then selling to the 6 consumers as modelled in the previous scenarios). Exhaust heat from the engines would be used 7 to satisfy the heating demand and would also be supplied to absorption chillers for producing 8 cooling. For backup, natural gas boilers and a compression chiller are installed as well. Details of 9 all energy conversion units installed in BAU scenario are shown in Table 14. 
Table 9: Technical specifications of equipment installed in BAU scenario (2020-2030)

\begin{tabular}{|c|c|c|c|c|c|}
\hline \multirow[t]{2}{*}{$\begin{array}{c}\text { Energy } \\
\text { Conversion unit }\end{array}$} & \multirow[t]{2}{*}{ Specifications } & \multicolumn{3}{|c|}{$\begin{array}{c}\text { Quantity installed each } \\
\text { year }\end{array}$} & \multirow{2}{*}{$\begin{array}{c}\text { Total installed } \\
\text { capacity by } \\
2030\end{array}$} \\
\hline & & 2020 & 2025 & 2030 & \\
\hline $\begin{array}{l}\text { Cogeneration } \\
\text { engines }\end{array}$ & $\begin{array}{l}3,350 \mathrm{~kW}_{\mathrm{e}} ; 3,280 \mathrm{~kW}_{\mathrm{th}, \mathrm{h}} \\
\eta_{\mathrm{el}}=44.9 \% ; \eta_{\mathrm{th}}=41.1 \%\end{array}$ & 3 & 1 & 5 & $\begin{array}{l}30,150 \mathrm{~kW}_{\mathrm{e}} \\
29,520 \mathrm{~kW}_{\text {th,h }}\end{array}$ \\
\hline $\begin{array}{c}\text { Double effect abs } \\
\text { orption chillers }\end{array}$ & $5,000 \mathrm{~kW}_{\mathrm{th}, \mathrm{c}} ; \mathrm{COP}=1.3$ & 1 & 1 & 2 & $20,000 \mathrm{~kW}_{\mathrm{th}, \mathrm{c}}$ \\
\hline $\begin{array}{c}\text { Single effect abso } \\
\text { rption } \\
\text { chillers }\end{array}$ & $3,000 \mathrm{~kW}_{\mathrm{th}, \mathrm{c}} ; \mathrm{COP}=0.75$ & - & 2 & 1 & $9,000 \mathrm{~kW}_{\text {th,c }}$ \\
\hline $\begin{array}{c}\text { Natural gas boiler } \\
\text { s }\end{array}$ & $5,000 \mathrm{~kW}_{\mathrm{th}, \mathrm{h}} ; \eta_{\mathrm{th}}=60 \%$ & $\begin{array}{c}1 \\
\text { (back } \\
\text { up) }\end{array}$ & 2 & - & $15,000 \mathrm{~kW}_{\text {th,h }}$ \\
\hline $\begin{array}{c}\text { Compression chill } \\
\text { er }\end{array}$ & $15,000 \mathrm{~kW}_{\mathrm{th}, \mathrm{c}} ; \mathrm{COP}=4$ & - & 1 & - & $15,000 \mathrm{~kW}_{\text {th,c }}$ \\
\hline
\end{tabular}

\section{5. Economic modeling}

4 Fuel prices provided to the EnergyPRO models from 2016 to 2030 are shown in the Appendix.

5 Prices of natural gas and electricity have been inflated according to the percentages explained in

6 section 2 while landfill gas and biomass are inflated at $2 \%$ (inflation rate of the Euro region). The

7 price and maintenance costs of the biogas boiler (having a capacity of $1.5 \mathrm{MW}_{\mathrm{th}, \mathrm{h}}$ ), installed in

82017 , are $€ 147,500$ and $€ 6,250$ respectively. Investment costs of various equipment in the

9 different scenarios were available for present day and are inflated at $2 \%$ every year, so as to get

10 the expected cost of the actual year in which they were integrated in the models.

11 Table 10: Investment costs of cold and hot storage tanks at ST-5 plant shows costs of the cold [25]

12 and hot storage tanks [36] installed at ST-5 from 2020 to 2025. The specifications of these

13 storage tanks have been shown previously shown in Table 5. 
Table 10: Investment costs of cold and hot storage tanks at ST-5 plant

\begin{tabular}{cccc}
\hline & $\mathbf{2 0 2 0}$ & $\mathbf{2 0 2 5}$ & $\mathbf{2 0 3 0}$ \\
\hline Cold water storage tank & $€ 1,400,000$ & $€ 2,700,000$ & $€ 2,600,000$ \\
Hot water storage tank & $€ 97,400$ & $€ 290,000$ & $€ 237,500$ \\
\hline
\end{tabular}

2

3 Cost of the new equipment installed at ST-4 plant in 2025 is shown in Table 11. Cost of engines 4 and double effect absorption chillers have been provided by the management at Parc de l' Alba

Table 11: Investment cost of engines and chiller at ST-4 plant in 2025

\begin{tabular}{|c|c|c|}
\hline Energy Conversion unit & Specifications & Total investment \\
\hline Cogeneration engines & $3350 \mathrm{~kW}_{\mathrm{e}} ; 3280 \mathrm{~kW}$ th, $; \eta_{\mathrm{el}}=44.9 \%$ & $€ 3,700,000$ \\
\hline $\begin{array}{l}\text { Double effect absorption } \\
\text { chiller }\end{array}$ & $5000 \mathrm{~kW}_{\mathrm{th}, \mathrm{c}} ; \mathrm{COP}=1.3$ & $€ 1,100,000$ \\
\hline
\end{tabular}

7 For the ST-5 plant, the CAPEX of the SCBC, GSHPs and BAU scenarios are shown in Table 12, 8 Table 13 and Table 14 respectively. 
Table 12: Investment costs of energy conversion units installed in SCBC scenario

Energy Conversion unit

Parabolic trough collectors

Absorption chiller (connected

to solar collectors)

Auxiliary equipment for solar

thermal cooling system

Biomass boiler

$€ 1,172,000$
2030

$€ 353,000$

$€ 277,000$

$€ 631,000$

Total investment

2025 
Table 14: Investment costs of energy conversion units installed in BAU scenario

Energy Conversion unit

\begin{tabular}{cccc}
\cline { 2 - 4 } & $\mathbf{2 0 2 0}$ & $\mathbf{2 0 2 5}$ & $\mathbf{2 0 3 0}$ \\
\hline $\begin{array}{c}\text { Cogeneration } \\
\text { engines }\end{array}$ & $€ 4,931,000$ & $€ 1,815,000$ & $€ 10,020,000$ \\
$\begin{array}{c}\text { Double effect } \\
\text { absorption chillers } \\
\text { Single effect } \\
\text { absorption chillers } \\
\text { Natural gas boilers }\end{array}$ & $€ 998,000$ & - & $€ 1,216,000$ \\
Compression chiller & $€ 123,000$ & $€ 272,000$ & $€ 1,460,000$ \\
& - & $€ 1,484,000$ & - \\
\hline
\end{tabular}

3 Cost of the solar collectors was provided by a manufacturer based in Sweden [37], while the

4 price of the absorption chiller was taken from [38]. For the GSHPs scenario, investment and

5 maintenance costs were taken from a study carried out in France [39], including cost of drilling

6 in the ground and construction of boreholes. Costs of the solar PV system were taken from IEA

7 [40]. In the BAU scenario, investment costs of engines and natural gas boilers were provided by

8 Parc de l' Alba management, while cost of the compression chiller was calculated from a guide

9 published by the Catalan Energy Institute [41].

\section{6. Results and Discussion}

11 This section presents key results of the EnergyPRO simulations and economic analysis. Results

12 are shown in a chronological order, i.e., first of the years 2016 till 2018 and then of 2020 till

132030 for the different scenarios.

\section{6.1. Energy Performance}

15 From 2016 till 2018, all three scenarios have identical simulation models. Energy balance of 16 2016-2018 is shown in Table 15. Energy demand may be seen in Figure 2 andFigure 3 in section

17 3. It must be stressed here that energy consumption refers to the actual amount of energy 
1 consumed while primary energy consumed is the total energy required to produce one unit of a

2 consumed particular energy on site; including transportation, storage, distribution, delivery and

3 any losses incurred in the process.

$2016 \quad 2017$

\section{Energy Consumption(MWh/year)}

Imported Electricity

Natural gas

Biogas
16,800

92,900

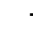

\section{Primary Energy Consumption(MWh/year)}

Imported electricity

Natural gas

Biogas

Total
39,900

111,000

$-$

151,000
9,200

17,000

94,900
9,100

17,000

92,000 


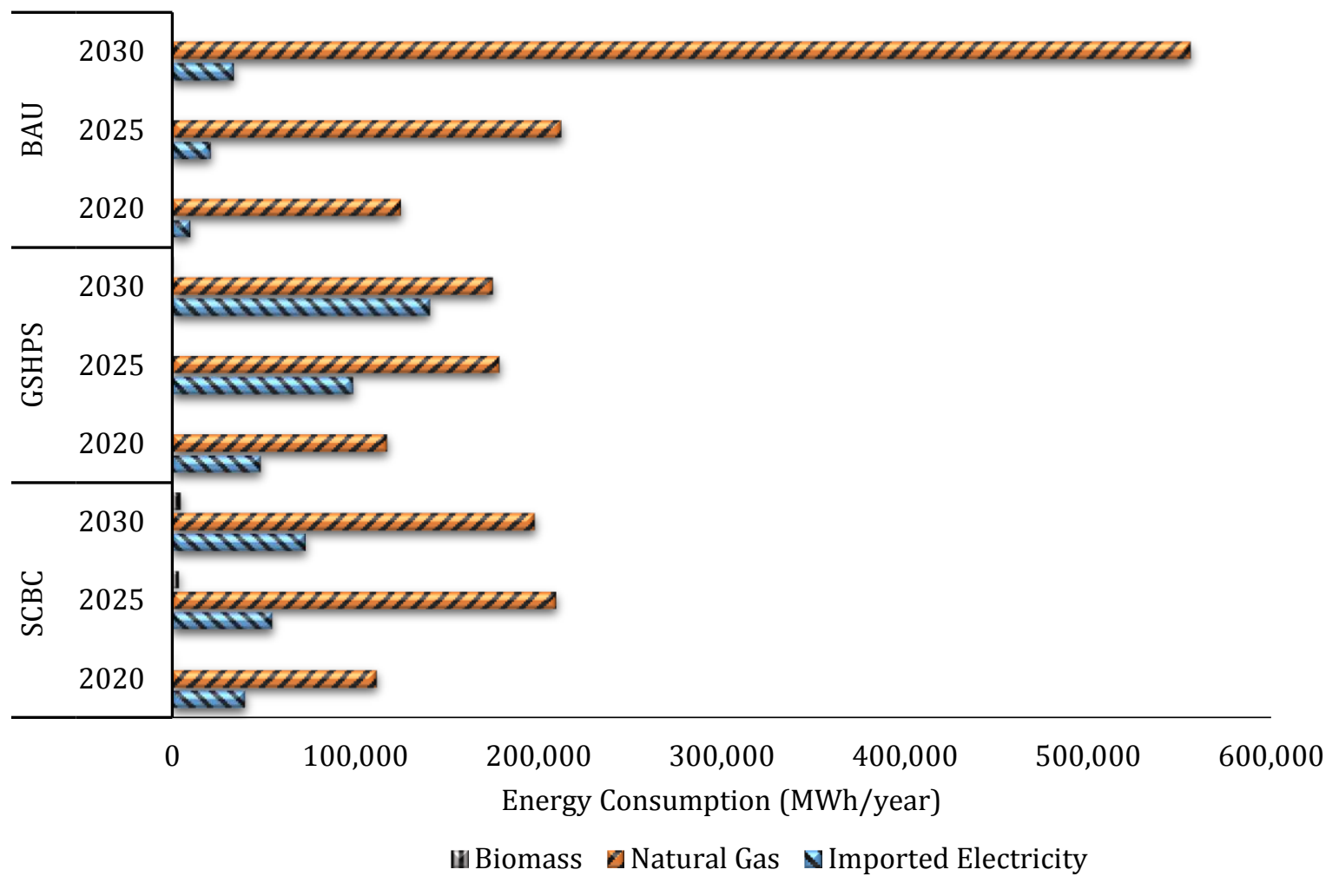

2 Figure 11: Energy Balance for different scenario of the basis of energy consumption (MWh/year) 


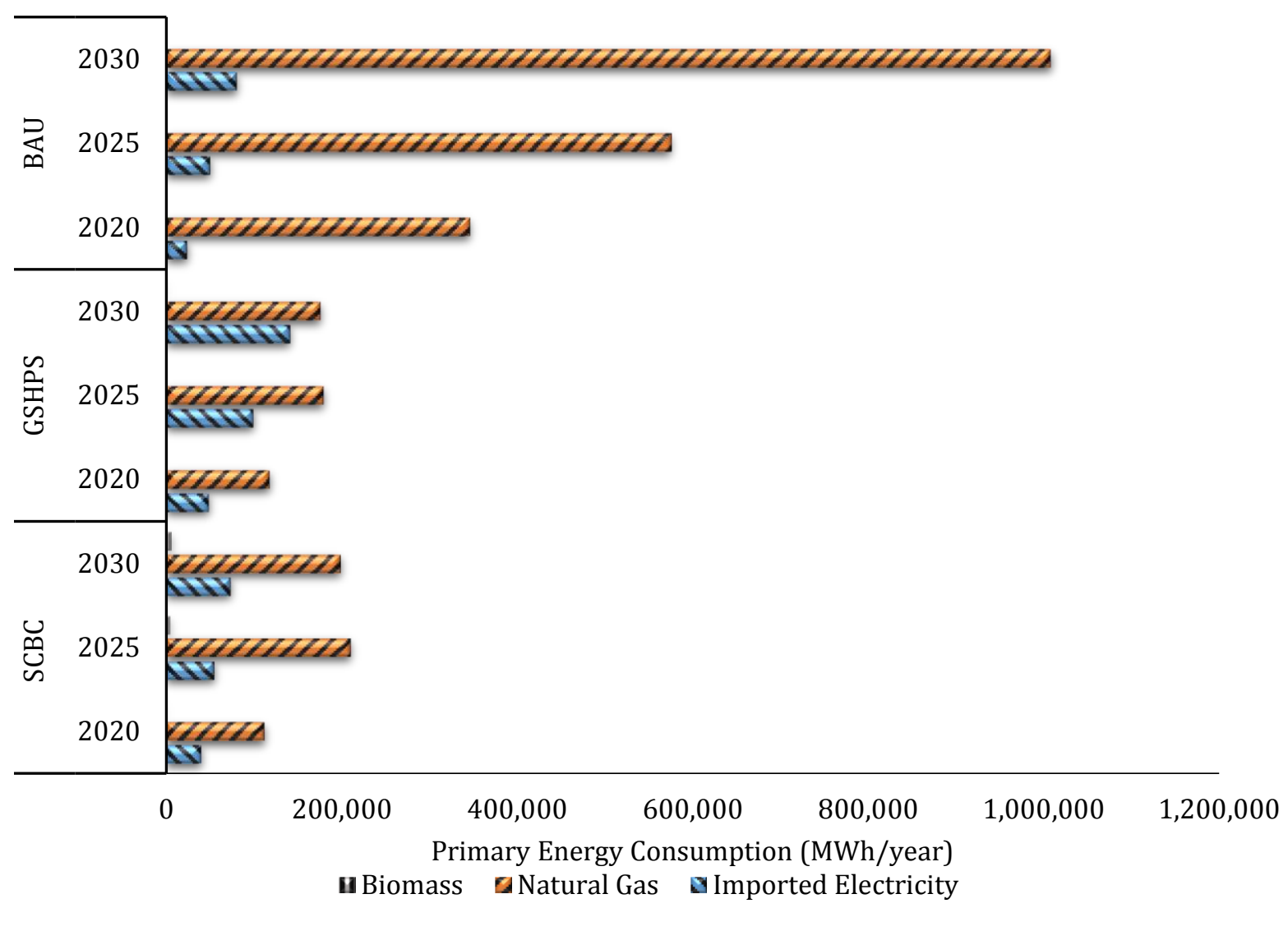

Figure 12: Energy Balance for different scenarios on the basis of primary energy consumption

(MWh/year)

4 By comparison between Figure 11 and Figure 12, it can be seen that the GSHPs scenario has a 5 larger energy and primary energy consumption as compared the SCBC scenario. This is because 6 of the fact that the former relies more on electricity to run the GSHP units while the latter uses 7 biomass as the main fuel, which has a lower PEF as shown previously in Table 4 in section 2.

8 The BAU scenario has a drastically larger consumption of energy, which is clearly due to 9 burning of much more natural gas. The new ST-5 plant in this case relies only on the new 10 cogeneration engines for energy production. Moreover, the old engines in the ST-4 plant are 11 running more hours in comparison with SCBC and GSHPs scenario, since there are no RES 12 based energy conversion units in BAU scenario. Moreover, as explained previously, in the BAU 13 scenario the backup boiler at the ST-4 plant is allowed to operate throughout the year and not 
1 only in winter months as in the SCBC and GSHPs scenario, where priority is to run the RES

2 based units.

$3 \quad$ 6.2. Environmental analysis

4 Table 16 shows the $\mathrm{CO}_{2}$ emissions from 2016 until 2018, while emissions from 2020 until 2030 5 are shown in Table 17.

Table 16: $\mathrm{CO}_{2}$ emissions in Parc de l' Alba from 2016 until 2018

\begin{tabular}{lccc}
\hline & $\mathbf{2 0 1 6}$ & $\mathbf{2 0 1 7}$ & $\mathbf{2 0 1 8}$ \\
\hline CO2 emissions (tons/year) & 29,400 & 30,900 & 30,400 \\
\hline
\end{tabular}

\begin{tabular}{cccc}
\hline & $\mathbf{2 0 2 0}$ & $\mathbf{2 0 2 5}$ & $\mathbf{2 0 3 0}$ \\
\hline SCBC scenario (tons/year) & 38,600 & 71,800 & 107,800 \\
GSHPs scenario (tons/year) & 40,800 & 70,300 & 111,170 \\
BAU scenario (tons/year) & 76,300 & 128,500 & 224,500 \\
\hline
\end{tabular}

10 From Table 17, BAU scenario shows more than twice the amount of $\mathrm{CO}_{2}$ emissions in 2030, 11 mainly because it is burning more natural gas in comparison to the RES based scenarios, due to 12 the new cogeneration engines and new boilers at ST-5 plant and longer running hours of the old 13 engines and old boiler at the ST-4 plant.

\section{$14 \quad$ 6.3. Economic results}

15 The major economic indicators obtained from the EnergyPRO simulations and the P \& $\mathrm{L}$ 16 analysis are mainly the revenues, operating costs, EBITDA (Earnings before Interests, Taxes, 17 Depreciation and Amortization) and NPV. Figure 13 show all these indicators (except NPV) for 18 2016-2018 and 2020-2030 respectively. 
Table 18: Economic indicators of Parc de l' Alba from 2016 till 2018

\begin{tabular}{cccc}
\hline & $\mathbf{2 0 1 6}$ & $\mathbf{2 0 1 7}$ & $\mathbf{2 0 1 8}$ \\
\hline Revenues & $€ 7,651,000$ & $€ 8,820,000$ & $€ 10,155,000$ \\
Operating Costs & $€ 5,080,000$ & $€ 5,604,000$ & $€ 5,887,000$ \\
FBITDA & $€ 2,571,000$ & $€ 3,216,000$ & $€ 4,268,000$ \\
\hline
\end{tabular}

2

3 The NPV is calculated until the end period for each scenario and is thus shown graphically in 4 Figure 14: Net Present Value (NPV) of each scenario for each scenario.

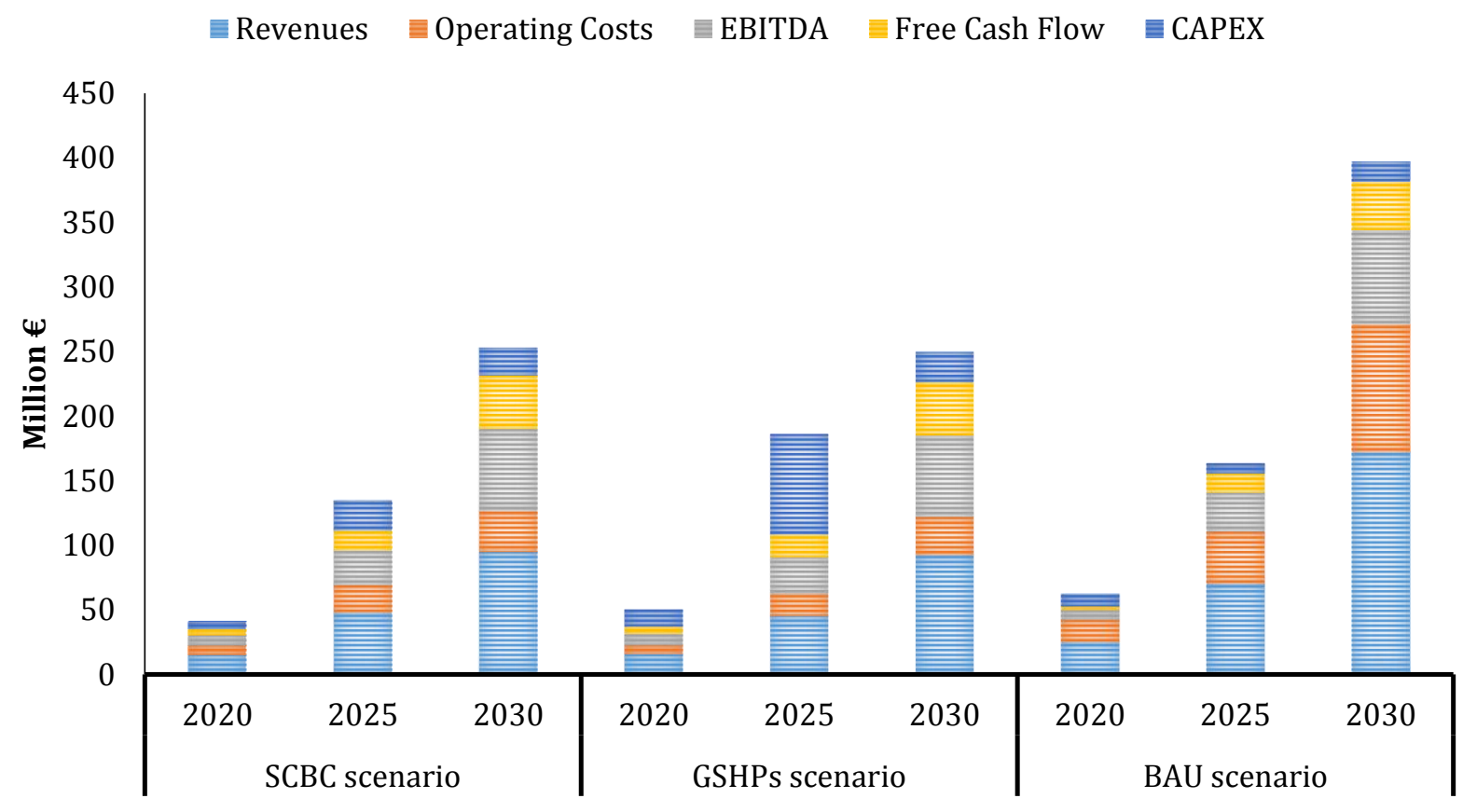

Scenario

Figure 13: Economic indicators of the different scenarios 


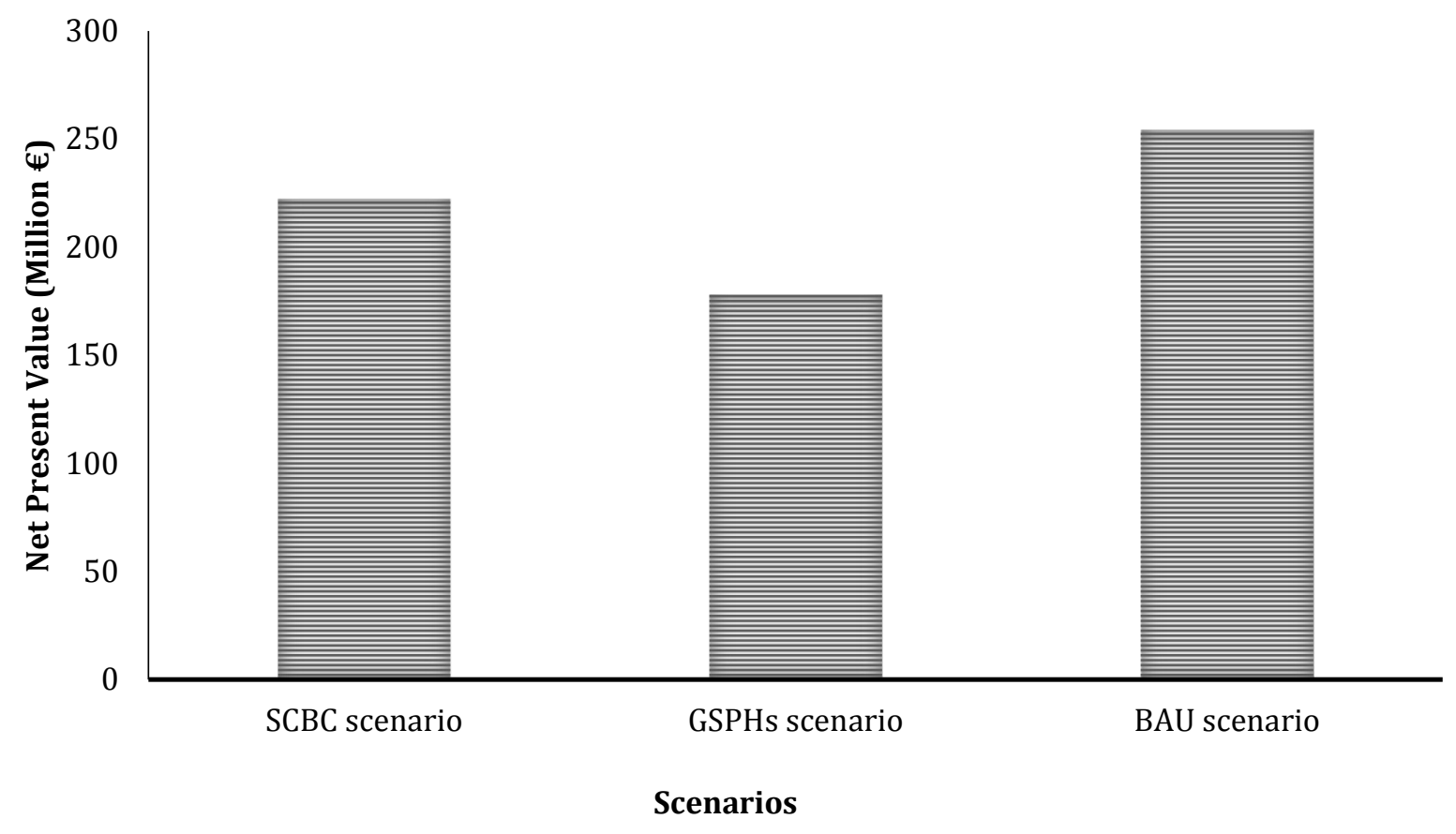

3 By comparing the two RES based scenarios from Figure 13 and Figure 14, it can be seen clearly 4 that the SCBC scenario is more profitable in comparison to GSHPs scenario, due to its lower 5 CAPEX and higher NPV. Apparently, GSHPs have an average efficiency which is four times

6 that of boilers burning biomass and providing heat to absorption chillers in the SCBC scenario.

7 However, the CAPEX in the GSHPs scenario is much higher than SCBC scenario and moreover, 8 cost of imported electricity is higher than biomass and it increases at a faster rate (than that of 9 biomass), as explained in section 2.

10 When doing the comparison as a whole, it is indeed the BAU scenario which is most profitable.

11 Not only does it have the lowest CAPEX in comparison to the RES based scenarios, but it has an 12 additional revenue stream generated by exporting excess electricity produced to the grid.

\section{Conclusion}

14 The paper presents a technical, economic and environmental evaluation of implementing 15 different RES based systems in the expansion of a fossil fuels based DHC plant in a Technology 16 Park in the region of Catalonia in Spain. The expansion of the existing plant was dictated by the 17 forecast of increased demand of cooling, heating and electricity in the Technology Park. The aim 
1 of the study was to evaluate which combination of RES based systems would be best suited for

2 integrating into the expansion of the DHC plant.

3 In context of the given assumptions and input parameters, the results of the simulations and 4 economic evaluation showed that when deciding between RES based technologies, SCBC 5 scenario is more feasible option when compared to the GSHPs scenario, due to its lower primary 6 energy consumption (624,380 MWh/year in 2030 vs. 665,367 MWh/year), lower $\mathrm{CO}_{2}$ emissions 7 (107,753 tons/year in 2030 vs. 111,166 tons/year) and higher NPV (222 million $€$ vs. 178 million $8 €)$ with lower CAPEX.

9 Considering the SCBC scenario, solar thermal cooling has great prospects for primary energy 10 savings and reduction of $\mathrm{CO}_{2}$ emissions but in this study, the limited area of ST-5 plant's roof 11 was the reason that solar thermal cooling could not contribute a lot in the large cooling demand 12 of Parc de l'Alba. Only 2\% of the cooling demand in 2020 came from the solar thermal system, 13 dropping to a mere $1 \%$ in 2025 and 2030. This was not surprising because the maximum output 14 of the solar thermal cooling system installed was $417 \mathrm{~kW}_{\text {th,c }}$, whereas the total cooling capacity 15 of ST-5 plant was $3717 \mathrm{~kW}_{\text {th,c, }} 39,717 \mathrm{~kW}_{\text {th,c }}$ and 58,017 $\mathrm{kW}_{\text {th,c }}$ in 2020, 2025 and 2030 16 respectively. In the GSHPs scenario, the units are producing more heating than cooling, as 17 explained in section 4.2. For Parc de l' Alba, this excess heat is useless and hence rejected to the 18 soil. Basically, implementation of GSHPs for simultaneous production of cooling and heating is 19 not feasible for office buildings and data centers located in a Mediterranean climate (Catalonia), 20 where cooling is the main energy demand and not heating. Additionally, digging of boreholes for 21 installation of GSHPs requires large land areas, an additional investment that has to be taken into 22 account.

23 In contrast to solar thermal cooling and GSHPs, biomass boilers burning woodchips connected to 24 double effect absorption chillers are apparently the most favorable solution in this study. Not 25 only is biomass cheaper than importing electricity, but there are large savings in primary energy 26 consumption as well (wood chips and electricity have PEFs of 0.034 and 2.368 respectively as 27 shown in table 7). Moreover, for the same cooling capacities, biomass boilers and absorption 28 chillers need less land area for installation as compared to GSHPs and solar thermal cooling 29 systems. 
1 Thus, in the frame of this study, based on the given assumptions and inputs, biomass boilers

2 connected to absorption chillers with assistance from solar thermal cooling are the most feasible

3 renewable energy system technology, for the large district heating and cooling network of Parc

4 de l'Alba in Spain.

\section{Acknowledgment}

6 The paper has been written in the framework of the Smart ReFlex project (Smart and Flexible

7 100\% Renewable District Heating and Cooling Systems for European Cities), co-funded by the

8 Intelligent Energy Europe Programme of the European Union by means of Grant Agreement

9 number IEE/13/434/SI2.674873. As a consequence, the EnergyPRO software, which is

10 sponsored by EMD International A/S for SMARTREFLEX, has been used to develop energy

11 calculations. Carlos Dapena, Project Manager from Consorci Urbanístic del Centre Direccional

12 de Cerdanyola del Vallès (Parc de l' Alba) and José Antonio Gómez, General Manager of ST4

13 Plant in Parc de 1' Alba from Grupo San José have contributed providing data about real

14 performance and future development planning of DHC in Parc de l' Alba.

15 The authors are thus thankful to all the afore mentioned entities and persons who have 16 contributed indirectly to the writing of this paper. 


\section{References}

2 [1] European Commission, "2030 climate \& energy framework _ Climate Action," 2017. .

4 [2] European Comission, "Buildings - European Commission," Energy, 2014. .

5 [3] European Commission, "EUR-Lex - 32012L0027 - EN - EUR-Lex,” 2015. .

6 [4] H. Dagdougui, R. Minciardi, A. Ouammi, M. Robba, and R. Sacile, "Modeling and 7 optimization of a hybrid system for the energy supply of a 'green' building," Energy Convers. Manag., vol. 64, pp. 351-363, 2012.

9 [5] H. Wang, W. Yin, E. Abdollahi, R. Lahdelma, and W. Jiao, "Modelling and optimization of CHP based district heating system with renewable energy production and energy storage," Appl. Energy, vol. 159, pp. 401-421, 2015.

P. A. Østergaard, "Comparing electricity, heat and biogas storages' impacts on renewable energy integration," Energy, vol. 37, no. 1, pp. 255-262, 2012.

[7] S. Nielsen and B.

B. Möller, "Excess heat production of future net zero energy buildings within district heating areas in Denmark," Energy, vol. 48, no. 1, pp. 23$31,2012$.

G. Streckiene, V. Martinaitis, A. N. Andersen, and J. Katz, "Feasibility of CHPplants with thermal stores in the German spot market," vol. 86, pp. 2308-2316, 2009.

[9] H. Lund, G. Šiupšinskas, and V. Martinaitis, "Implementation strategy for small CHP-plants in a competitive market: The case of Lithuania," Appl. Energy, vol. 82, no. 3, pp. 214-227, 2005.

[10] O. Arslan and R. Kose, "Exergoeconomic optimization of integrated geothermal system in Simav, Kutahya," Energy Convers. Manag., vol. 51, no. 4, pp. 663-676, 2010. 
[11] M. De Carli, A. Galgaro, M. Pasqualetto, and A. Zarrella, "Energetic and economic aspects of a heating and cooling district in a mild climate based on closed loop ground source heat pump," Appl. Therm. Eng., vol. 71, no. 2, pp. 895-904, 2014.

[12] A. Hakkaki-Fard, P. Eslami-Nejad, Z. Aidoun, and M. Ouzzane, "A technoeconomic comparison of a direct expansion ground-source and an air-source heat pump system in Canadian cold climates," Energy, vol. 87, pp. 49-59, 2015.

[13] G. Angrisani, G. Diglio, M. Sasso, F. Calise, and M. Dentice d'Accadia, "Design of a novel geothermal heating and cooling system: Energy and economic analysis," Energy Convers. Manag., vol. 108, pp. 144-159, 2016.

[14] M. Tan and A. Keçebas, "Thermodynamic and economic evaluations of a geothermal district heating system using advanced exergy-based methods," vol. 77, pp. 504-513, 2014.

[15] A. Keçebaş and A. Hepbasli, "Conventional and advanced exergoeconomic analyses of geothermal district heating systems," Energy Build., vol. 69, pp. 434$441,2014$.

[16] A. Baghernejad, M. Yaghoubi, and K. Jafarpur, "Exergoeconomic optimization and environmental analysis of a novel solar-trigeneration system for heating, cooling and power production purpose," Sol. Energy, vol. 134, pp. 165-179, 2016.

[17] D. Buoro, P. Pinamonti, and M. Reini, "Optimization of a Distributed Cogeneration System with solar district heating," Appl. Energy, vol. 124, pp. 298-308, 2014.

[18] M. F. Torchio, "Comparison of district heating CHP and distributed generation CHP with energy, environmental and economic criteria for Northern Italy," Energy Convers. Manag., vol. 92, pp. 114-128, 2015.

[19] V. M. Soltero, "Evaluation of the potential for District Heating Cogeneration in Spain as a tool for economy decarbonization,” pp. 1-21, 2016. 
[20] A. Kazagic, A. Merzic, E. Redzic, and D. Tresnjo, "Optimization of modular district heating solution based on CHP and RES - Demonstration case of the Municipality of Visoko," Energy, vol. 181, pp. 56-65, 2019.

[21] M. Rämä and M. Wahlroos, "Introduction of new decentralised renewable heat supply in an existing district heating system," Energy, vol. 154, pp. 68-79, 2018.

[22] M. E. Martínez and C. Martín-gómez, "Reasons Why District Energy Systems Were Not Extended in Spain," in 39th World Congress on Housing Science Changing Needs, Adaptive Buildings, Smart Cities. Politecnico di Milano, Italy, 2013.

[23] EMD International A/S, "energyPRO." .

[24] “• Spain: Electricity prices for households 2010-2018 | Statistic." [Online]. Available: https://www.statista.com/statistics/418085/electricity-prices-forhouseholds-in-spain/. [Accessed: 08-Jun-2019].

[25] C. Dapena, "Consorci Urbanístic del Centre Direccional de Cerdanyola del Vallès ,Parc de l'Alba (personal communication).” 2016.

[26] LOGSTOR, "Calculator for insulation on LOGSTOR pipes." [Online]. Available: https://www.logstor.com/service-support/tools/logstor-calculator. [Accessed: 09Jun-2019].

[27] E. y T. Ministerio de Industria, "Factores de emisión de CO2 y coeficientes de paso a energía primaria de diferentes fuentes de energía final consumidas en el sector de edificios en España (in Spanish)," 2014.

[28] J. S. Gunn, D. J. Ganz, and W. S. Keeton, "Biogenic vs. geologic carbon emissions and forest biomass energy production," GCB Bioenergy, vol. 4, no. 3, pp. 239-242, 2012.

[29] S. Ross, R. Westerfield, and B. Jordan, Fundamentals of Corporate Finance, 11th 
ed. New York: McGraw-Hill, 2014.

2 [30] International Energy Agency (IEA), Energy Policies of IEA Countries - Spain 2015 Review. 2015.

4 [31] European Central Bank, "Monetary Policy," 2010. .

5 [32] Ajuntament de Barcelona, "Pla de Millora Energética de Barcelona," Barcelona, 6 2002.

[33] R. Ulseth and L. Pedersen, "Method for load modelling of heat and electricity demand," in 10th International Symposium on District Heating and Cooling, 2006, no. September.

[34] European Commission, "Energy requirements for IT equipment - Renewit: Renewit." .

12 [35] FuturENERGY, "Hospital de Mollet, energy efficiency and sustainability FuturEnergy," 2016. .

14 [36] T. Schmidt and O. Miedaner, "Solar district heating guidelines - Storage," Solar district heating guidelines, 2012. .

16 [37] A. Rammsy, "Absolicon Solar Collectors AB (personal communication, 2016)." Stockholm, 2016.

[38] A. Shirazi, R. A. Taylor, S. D. White, and G. L. Morrison, “A systematic parametric study and feasibility assessment absorption chillers for heating and cooling applications," ENERGY Convers. Manag., vol. 114, pp. 258-277, 2016.

[39] C. Boissavy, "Cost and Return on Investment for Geothermal Heat Pump Systems in France," 2015, no. April, pp. 19-25.

23 [40] International Energy Agency (IEA), “Technology Roadmap - Solar Photovoltaic Energy," 2014. 
1 [41] Institut Català d'Energia (ICAEN), "Guia de desenvolupament de projectes de 2 xarxes de Districte de Calor i Frio,” 2010.

10

11

12

13

14

15

16

17

18

19

20 


\section{Appendix}

2 For the ST-4 plant at Parc de l' Alba, revenues from heating, cooling and electricity sales

3 comprise of capacity payments and a variable price. Additionally, heating and cooling sale

4 revenues comprise of a connection payment. The connection costs are paid just once whenever a

5 new consumer in Parc de l' Alba signs an agreement to buy heating and cooling from the plant.

6 The capacity payment refers to payment made every year by the consumer in accordance with

7 the power they have contracted from the plant. Finally, the variable price is payment made by the

8 consumer for each unit of energy purchased. Table 19 and Table 20 show details of all these

9 revenues for the year 2015.

$10 \quad$ Table 19: Revenues from heating and cooling sales at Parc de l'Alba for base model (2015)

\begin{tabular}{ccc}
\hline Payment type & Value for cooling & Value for heating \\
\hline Connection payment & $14,580 € / \mathrm{MW}_{\mathrm{th}, \mathrm{c}}$ connected & $48,200 € / \mathrm{MW}_{\mathrm{th}, \mathrm{h}}$ connected \\
Capacity payment & $23,000 € / \mathrm{MW}_{\mathrm{th}, \mathrm{c}} / \mathrm{year}$ & $14,000 € / \mathrm{MW}_{\mathrm{th}, \mathrm{h}} / \mathrm{year}$ \\
Variable price & $34.8 € / \mathrm{MWh}_{\mathrm{th}, \mathrm{c}}$ sold & $34.8 € / \mathrm{MWh}_{\mathrm{th}, \mathrm{h}}$ sold \\
\hline
\end{tabular}

Payment type Value for electricity (Synchrotron) Value for electricity (grid)

Capacity payment

$617,130 € /$ year

114.2 $€ / \mathrm{MWh}_{\mathrm{e}}$ sold
$529,200 € /$ year

113.2 $€ / \mathrm{MWh}_{\mathrm{e}}$ sold

14 All expenses of the plant are shown in Table 21 and Table 22 for 2015. Note that Parc de l' Alba

15 pays only the marginal electricity production cost when it buys from the electric grid and hence

16 the large difference between the revenue it earns per unit energy by selling to the grid, compared

17 to what it pays per unit when it needs to purchase from the grid. 


\begin{tabular}{cc}
\hline Fuel & Value \\
\hline Natural gas & $37.8 € / \mathrm{MWh}_{\text {th }}\left(0.402 € / \mathrm{m}^{3}\right)$ \\
Electricity imported & $40.7 € / \mathrm{MWh}_{\mathrm{e}}$ \\
\hline
\end{tabular}

3

4

\begin{tabular}{cc}
\hline Maintenance type & Value \\
\hline Fixed maintenance & $245,100 € /$ year \\
Variable maintenance & $13.3 € / \mathrm{MWh}_{\mathrm{e}}$ from gas engines \\
Overhaul of engines & $6.8 € /$ hour operation
\end{tabular}

Table 22: Maintenance expenses at Parc de l' Alba in 2015
5

6 7

\begin{tabular}{|c|c|c|c|c|c|c|}
\hline Year & 2016 & 2017 & 2018 & 2020 & 2025 & 2030 \\
\hline $\begin{array}{l}\text { Natural gas } \\
(€ / \mathbf{k W h} \text { th) }\end{array}$ & 0.040 & 0.043 & 0.046 & 0.050 & 0.072 & 0.104 \\
\hline $\begin{array}{l}\text { Imported } \\
\text { electricity }\left(€ / k W h_{e}\right)\end{array}$ & 0.041 & 0.045 & 0.049 & $\begin{array}{l}0.060- \\
0.068\end{array}$ & $\begin{array}{l}0.094- \\
0.129\end{array}$ & $\begin{array}{l}0.149- \\
0.212\end{array}$ \\
\hline $\begin{array}{l}\text { Landfill gas } \\
\left(€ / \mathbf{k} \mathbf{W h}_{\text {th }}\right)\end{array}$ & - & 0.0082 & 0.0083 & - & - & - \\
\hline $\operatorname{Biomass}\left(€ / \mathbf{k} \mathbf{W h}_{\text {th }}\right)$ & - & - & - & 0.033 & 0.036 & 0.040 \\
\hline
\end{tabular}

Table 23: Fuel prices in Parc de l' Alba from 2016 till 2030

Fuel prices provided to the EnergyPRO models from 2016 to 2030 are shown in Table 23 [25].

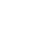

急 
1 The specifications of different categories of energy consumers at Parc de 1' Alba, including

2 current and future ones, are shown in Table 24 , including the year in which they will be

3 connected to the DHC network.

Table 24: Details of expected energy consumers of Parc de l' Alba till 2030

\begin{tabular}{cccccc}
\hline $\begin{array}{c}\text { Consumer } \\
\text { name in } \\
\text { software } \\
\text { Model }\end{array}$ & $\begin{array}{c}\text { Consumer } \\
\text { type }\end{array}$ & $\begin{array}{c}\text { Energy service(s) } \\
\text { provided }\end{array}$ & $\begin{array}{c}\text { Year of } \\
\text { connection }\end{array}$ & $\begin{array}{c}\text { Number of } \\
\text { building(s) }\end{array}$ & $\begin{array}{c}\text { Total floor } \\
\text { area }\left(\mathbf{m}^{\mathbf{2}}\right)\end{array}$ \\
\hline Synchrotron & Particle & Heating, Cooling, & 2010 & 1 & 35,000 \\
Accelerator & Electricity & & & \\
Plot 1 & Offices & Heating, Cooling & 2013 & 1 & 43,000 \\
Plot 2 & Data Center & Cooling & 2016 & 1 & 51,230 \\
Plot 3 & Offices & Heating, Cooling & 2017 & 1 & 81,230 \\
Plot 4 & Offices & Heating, Cooling & 2018 & 1 & 89,230 \\
Plots 2020-DC & Data Center & Cooling, Electricity & 2020 & 1 & 93,230 \\
Plots 2020-Off & Offices & Heating, Cooling & 2020 & 2 & 108,230 \\
Plots 2025-DC & Data Center & Cooling, Electricity & 2025 & 1 & 112,230 \\
Plots 2025-Off & Offices & Heating, Cooling & 2025 & 51 & 732,000 \\
Plots 2030-DC & Data Center & Cooling, Electricity & 2030 & 1 & 736,000 \\
Plots 2030-Off & Offices & Heating, Cooling & 2030 & 31 & 112,2000 \\
\hline & & & & & \\
\hline
\end{tabular}

6 EnergyPRO does not have the capability to dimension the distribution network because the 7 return and supply temperatures of the fluids in the network cannot be input to the simulation 8 models. For this purpose, LOGSTOR calculator, which is an internet-based program, was used 
1 for calculating the heating and cooling line losses. The major information used for calculating the

2 losses is shown in Table 25 . Note that the various sections of the DHC network had varying pipe

3 diameters.

Table 25: Parameters for calculating transmission and distribution losses for Parc de l' Alba

Parameter Value

Number of summer days

Number of winter days

Summer ambient temperature

Winter ambient temperature

Soil cover

Soil thermal conductivity

Pipe material

\section{2}

183

$19.5^{\circ} \mathrm{C}$

$11.6^{\circ} \mathrm{C}$

$1500 \mathrm{~mm}$

$1.6 \mathrm{~W} / \mathrm{m}-\mathrm{K}$

Steel

\section{Supply temperature}

$90^{\circ} \mathrm{C}$

District heating

Return temperature

$75^{\circ} \mathrm{C}$

Internal pipe diameters $(\mathrm{mm})$

$100 / 125 / 150 / 500$

Supply temperature

Return temperature

Internal pipe diameters ( $\mathrm{mm})$

Return temperature $5^{\circ} \mathrm{C}$

$12^{\circ} \mathrm{C}$

District cooling

$150 / 200 / 300 / 400 / 500 / 700 / 800$

5

6 